\title{
コンクリートのブリーディング量の予測式の作成に関する実験的研究 EXPERIMENTAL STUDY ON ESTABLISHMENT OF PREDICTION EQUATION OF BLEEDING OF CONCRETE
}

\author{
阿部道彦*, 仲摩 諭**, 鈴木 澄江 ***
}

\author{
Michihiko ABE, Satoru NAKAMA and Sumie SUZUKI
}

\begin{abstract}
This paper presents the results of experiment on the simple prediction model of bleeding of concrete. In the experiment, water cement ratio, unit water content and the kind of chemical admixture were varied. At the result of experiment, for the prediction of bleeding, only one constant coefficient need to be established. The value of this coefficient became the similar one in the plain concrete and the concrete with air-entraining agent. But that of concrete with air-entraining and water-reducing agent was a little bit larger than that of plain concrete. And the coefficient varied largely due to the lots of used material even if the brand or district was the same.
\end{abstract}

Keywords : Concrete, Bleeding, Prediction equation, Unit water content, Water cement ratio, Chemical admixture コンクリート, ブリーディング, 予測式, 単位水量, 水セメント比, 混和剂

\section{1. はじめに}

近年、環境配慮や鉄筋コンクリート造建築物に対する要求性能の 多様化により、コンクリートに使用される材料も多岐にわたってき ている。そして、それに伴いコンクリートのブリーディングがかな り多くなる場合も生じている。ブリーディングは、JIS A 0203 (コ ンクリート用語）に「フレッシュコンクリート及びフレッシュモル タルにおいて, 固体材料の沈降又は分離によって, 練混ぜ水の一部 が遊離して上昇する現象」と定義されているように、コンクリート を型枠の中に打ち込んだあとに生じる材料分離の一種であり、この 量が多すぎるとコンクリート部材上部の脆弱化や粗骨材および水平 鉄筋の下面への水の滞留による空隙の形成など、コンクリートの品 質の低下につながり、一方、その量が少な寸ぎると、高強度コンク リートなどでは、表面がこわばり、プラスチック収縮ひび割れが発 生しやすく、仕上げ作業に支障をきたす場合があるとされている 1)。 このため、1972 年にブリーディング量に関する規定が提案 2 さされて 以降、様々な規定が日本建築学会の仕様書や指針などに定められて きている。

しかしながら、ブリーディングに及ぼす各種要因の影響を実験結 果に基づいて定量的に評価する試みは少なく、具体的に規定值を満 足するための方法は提示されていない。このため本研究では、まず、 調合上の基本的な要因である単位水量（スランプ）および水セメン 卜比の影響を把握するための実験を行い、その結果に基づいて簡易 な予測式を作成することを試みた。次にその式を既往の予測式と比 較してその妥当性を検討した。さらに、コンクリート用化学混和剤 協会および建材試験センターより提供されたデータにより、 $\mathrm{AE}$ 剂、 $\mathrm{AE}$ 減水剤などの混和剤がブリーディングに及ぼす影響について検
討した。この論文は筆者らの既往の発表 3)-5)を再整理するとともに、 他の関連する既往の実験結果を整理して取りまとめたものである。 なお、JIS A 1123 (コンクリートのブリージング試験方法) は、ASTM C 232-53T (Tentative Standard Method for Bleeding of Concrete) に基づいて 1957 年に制定され、用語等の改正を重礼て 2012 年版 に至っており、本実験ではこの版に準じて試験を行っている。

\section{2. 実験概要}

実験は 4 つに分けて実施した。実験の概要を表 1 に示す。実験 1 では一般的なコンクリートのブリーディングの傾向を把握するため、 スランプおよび混和剤の種類を変化させた 9 種類のコンクリートに ついてブリーディング試験を行った。しかしながら、同一スランプ において、プレーンコンクリートのブリーディング量が混和剂を使 用したコンクリートの場合とあまり変わらないという結果が得られ た。そのため、同一水セメント比、同一スランプのコンクリートに おけるブリーディング量のばらつきを把握するため、実験 2 では水 セメント比 $55 \%$, スランプ $15 \mathrm{~cm}$ の場合について、プレーンコンク

\section{表 1 実験概要}

\begin{tabular}{|c|c|c|c|c|c|c|c|}
\hline $\begin{array}{l}\text { 実験 } \\
\text { No. }\end{array}$ & $\begin{array}{c}\text { 水セメント } \\
\text { 比 } \\
(\%)\end{array}$ & $\begin{array}{c}\text { スランプ } \\
(\mathrm{cm})\end{array}$ & 混和剈の種類 & $\begin{array}{c}1 \text { 調合 } \\
\text { 当たりの } \\
\text { バッチ数 }\end{array}$ & $\begin{array}{c}\text { 1バッチ } \\
\text { 当たりの } \\
\text { 測定回数 }\end{array}$ & \begin{tabular}{|c|} 
セメント \\
のロット \\
No.
\end{tabular} & $\begin{array}{c}\text { 細骨材 } \\
\text { のロット } \\
\text { No. }\end{array}$ \\
\hline 1 & 55 & $8,15,21$ & なし,AE剂,AE減水剤 & 1 & 2 & 1 & 1 \\
\hline 2 & 55 & 15 & なし, $\mathrm{AE}$ 凨, $\mathrm{AE}$ 減水剂 & 7 & 2 & 2 & 1 \\
\hline 3 & $45,55,65$ & $8,15,21$ & なし, $\mathrm{AE}$ 剂, $\mathrm{AE}$ 減水剤 & 1 & 1 & 2 & 1 \\
\hline 4 & 55 & 15 & なし,AE剤,AE減水剤 & 1 & 7 & 2 & 2 \\
\hline
\end{tabular}

* 工学院大学建築学部建築学科 教授 $\cdot$ 工博

** 東九州設計工務侏) 修士 (工学)

***＼cjkstart建材試験センター経営企画部 部長・博士(工学)
Prof., School of Architecture, Kogakuin Univ., Dr. Eng. Higashikyushu Architectural \& Engineering, Inc., M. Eng. Japan Testing Center for Construction Materials, Dr. Eng. 
リート、 $\mathrm{AE}$ 剂を使用したコンクリートおよび $\mathrm{AE}$ 減水剤を使用し たコンクリートについて日を変えてそれぞれ 7 バッチ練り、ブリー ディング試験を行った。

実験 3 ではブリーディングに及ぼす単位水量と混和剤の影響のほ か水セメント比の影響を把握するため、水セメント比を 3 水準に拡 張した。また、この実験では、1 バッチ当たりの測定回数を 2 回で はなく 1 回とした。これは、バッチ内のブリーディング量の差が少 ないと判断したためである。

検討の順序としては逆になるが、実験 4 ではバッチ内のばらつき を把握するため、実験 2 のコンクリートと同じ調合について、ブリ ーディング試験を同じバッチで 7 回行った。

なお、セメントおよび細骨材は同一銘柄、同一産地ではあるが、 表 1 に示すようにロットの異なるものを使用している。

\section{3. 実験方法}

\section{1 使用材料}

使用材料を表 2 に示す。セメント、細骨材および粗骨材はいずれ も一般的に使用されているもので、混和剂も $\mathrm{AE}$ 剂、 $\mathrm{AE}$ 減水剂とし て一般的な銘柄のものを選定した。

\section{2 調合}

実験 1 における単位水量および単位粗骨材かさ容積は、目標スラ ンプおよび適切なワーカビリティーとなるように、また、 $\mathrm{AE}$ 剂およ び $\mathrm{AE}$ 減水剂を使用したコンクリートの目標空気量は $4.5 \pm 0.5 \%$ と なるように、試し練りによって定め、この調合を実験 2 4 でも使用 した。単位粗骨材かさ容積 $\left(\mathrm{m}^{3} / \mathrm{m}^{3}\right)$ は、日本建築学会の調合設計指 針 ${ }^{6)}$ では、 $\mathrm{AE}$ 減水剂を使用した場合、水セメント比 $40 \sim 60 \%$ 、ス ランプ $8,15,21 \mathrm{~cm}$ に対してそれぞれ $0.68,0.66,0.58$ (上記指針の 2015 年の改定で $0.66,0.64,0.56)$ としているが、本実験では 0.64, 0.62, 0.54 となり、この值は混和剤の種類にかかわらず同一とした。

なお、実験 2 4 ではセメントのロットが、また、実験 4 では細骨 材のロットが異なっているが、目標スランプおよび目標空気量とな るように調合を調整することは行わなかった。

\section{3 練混ぜおよび試験方法}

コンクリートの練混ぜはパン型ミキサを用いて行い、細骨材とセ メントを入れて 30 秒、水を入れて 60 秒、粗骨材を入れて 90 秒練 り混ぜた。練混ぜ量は、実験 1〜3では容量 50L のミキサを用いて それぞれ 35、35、28L とし、また、実験 4 では容量 100L のミキサ

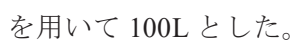

試験方法を表 3 に示す。ただし、ブリーディング試験における取 水は、JIS では最初の 60 分間は 10 分ごととなっているが、本実験

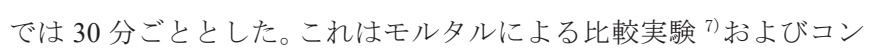
クリートによる比較実験 ${ }^{8)}$ によると、最初の 60 分間をいずれの方法 で行っても結果にほとんど影響しないとの報告に基づいて設定した ものである。

\section{4. 実験結果とその考察}

\section{1 調合、フレッシュ性状、圧縮強度の試験結果}

コンクリートの調合とフレッシュコンクリートおよび 4 週圧縮強 度の試験結果を表 4 に示す。なお、ブリーディング試験結果の表記 として JIS にはブリーディング量とブリーディング率があるが、建
表 2 使用材料

\begin{tabular}{|c|c|c|}
\hline 材料 & 種類または生産者 & 物性值等 \\
\hline セメント & 普通ポルトランドセメント & 実験1 4:密度: $3.16 \mathrm{~g} / \mathrm{cm}^{3}$ \\
\hline 細骨材 & 大井川水系陸砂 & $\begin{array}{l}\text { 実験 } 1 \sim 3 \text { : 表乾密度: } 2.56 \mathrm{~g} / \mathrm{cm}^{3} \text {, 実積率: } 68.0 \% \text {, 粗粒率: } 2.62 \\
\text { 実験 } 4: \quad \text { 表乾密度: } 2.59 \mathrm{~g} / \mathrm{cm}^{3} \text {, 実積率: } 66.0 \% \text {, 粗粒率: }: 2.77\end{array}$ \\
\hline 粗骨材 & $\begin{array}{l}\text { 青梅産硬質砂岩砕石 } \\
2013 \text { 21305等量混合 }\end{array}$ & 実験1 4:表乾密度:2.65g/ $\mathrm{cm}^{3}$ :実積率 $62.3 \%$ :粗粒率:6.74 \\
\hline 練混ぜ水 & 上水道水 & - \\
\hline \multirow{2}{*}{ 混和刘 } & $\mathrm{AE} \mathrm{n}_{\mathrm{a}}$ & アニオン系界面活性剤 \\
\hline & $\mathrm{AE}$ 減水剤:標準形 & リグニンスルホン酸化合物とポリオールの複合体 \\
\hline
\end{tabular}

表 3 試験方法

\begin{tabular}{|c||c|}
\hline 項目 & 試験方法 \\
\hline \hline スランプ試験 & JIS A 1101 \\
\hline 空気量試験 & JIS A 5308 \\
\hline 練上がり温度の測定 & アルコール温度計 \\
\hline フレッシュコンクリートの単位容積質量試験 & JIS A 1116 \\
\hline ブリーデイング試験 & JIS A 1123 \\
\hline 圧縮強度試験 & JIS A 1108 \\
(標準養生材齢4週) \\
\hline
\end{tabular}
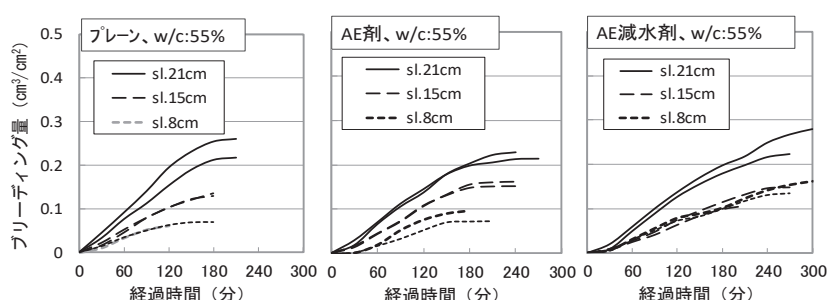

図 1 ブリーディング試験結果（実験 1 ）

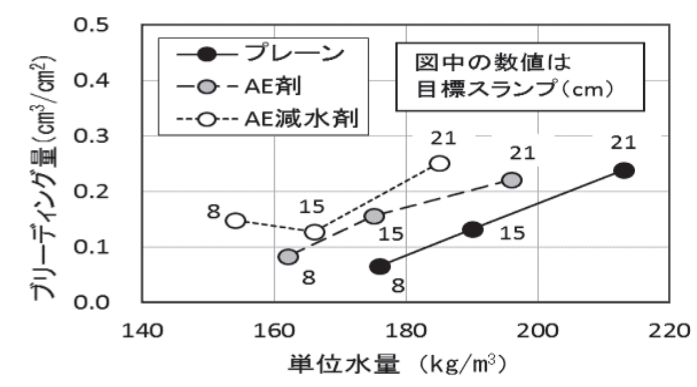

図 2 単位水量とブリーディング量の関係（実験 1)

築の分野ではブリーディングの規定が前者による表記となっている ため、本研究でも前者の表記とした。

\section{2 単位水量および混和剤の影響}

図 1 に実験 1 のブリーディング試験結果を示す。混和剤の種類ご とに同じ日に試験を行っている。これによると、同じ種類のコンク リートの場合、スランプが小さくなるとブリーディング量も減少す る傾向が確認された。ただし、AE 減水剂を使用した場合には表 4 の 実験 1 のデータから確認されるように、スランプ $15 \mathrm{~cm}$ と $8 \mathrm{~cm}$ でブ リーディング量に逆転が見られた。また、スランプが小さくなるほ ど、ブリーディングの終了する時間は短くなることが確認された。

図 2 に単位水量とブリーディング量の関係を示す。同一スランプ で比較した場合、プレーンコンクリートと混和剤を使用したコンク リートでは後者のほうが単位水量が少ないにもかかわらず、ブリー ディング量はあまり変わらないという結果になった。これは一般に 言われていることと矛盾する可能性があるため、これが試験のばら つきの範囲なのかどうかを確認するために、次の実験 2 を行った。

\section{3 バッチ間のブリーディング量のばらつき}

図 3 に日を変えて行った 7 バッチのブリーディング試験結果を示 
表 4 実験結果一覧

\begin{tabular}{|c|c|c|c|c|c|c|c|c|c|c|c|c|c|c|c|c|c|c|c|c|c|c|c|}
\hline \multirow{3}{*}{$\begin{array}{l}\text { 䒠 } \\
\text { 験 } \\
\text { No. }\end{array}$} & \multirow{3}{*}{$\begin{array}{c}\text { コンクリート } \\
\text { の種類 }\end{array}$} & \multirow{3}{*}{$\begin{array}{l}\text { 目標 } \\
\text { スラ } \\
\text { ンプ } \\
(\mathrm{cm})\end{array}$} & \multirow{3}{*}{\begin{tabular}{|c|} 
目標 \\
空気 \\
量 \\
$(\%)$
\end{tabular}} & & & & & & 質量 $(\mathrm{kg} / \mathrm{m}$ & & & & & 1- & & & & & & フレッ & 二性状 & & \\
\hline & & & & セメ & 粗骨材 & 細骨 & 単位 & & & & & & & $\left(\mathrm{cm}^{3} / \mathrm{c}\right.$ & & & & & & & & & \\
\hline & & & & $\begin{array}{c}\text { 比 } \\
(\%)\end{array}$ & $\begin{array}{c}\text { 稓 } \\
\left(\mathrm{m}^{\prime} / \mathrm{m}^{3}\right)\end{array}$ & $(\%)$ & $\left(\mathrm{kg} / \mathrm{m}^{3}\right)$ & ント & 細骨材 & 粗骨材 & & & 1 & 2 & 平均 & 1 & 2 & 平均 & & $(\%)$ & $\begin{array}{l}\text { 温度 } \\
\left({ }^{\circ} \mathrm{C}\right) \\
\end{array}$ & $\begin{array}{c}\text { 積質量 } \\
\left(\mathrm{kg} / \mathrm{m}^{3}\right)\end{array}$ & $\left(\mathrm{N} / \mathrm{mm}^{2}\right)$ \\
\hline & & \begin{tabular}{|l|}
21 \\
\end{tabular} & 1.0 & 55 & 0.54 & \begin{tabular}{|l|}
48.6 \\
\end{tabular} & 213 & 387 & 814 & \begin{tabular}{|l|}
892 \\
\end{tabular} & & & 0.217 & 0.260 & 0.239 & 210 & 210 & 210 & 21.0 & 0.0 & 20.5 & 2348 & 43.1 \\
\hline & プレーン & 15 & 1.0 & 55 & 0.62 & \begin{tabular}{|l|l|} 
& 44.1 \\
\end{tabular} & 190 & 345 & 779 & 1024 & & & \begin{tabular}{|l|}
0.129 \\
\end{tabular} & 0.135 & 0.132 & 180 & 180 & 180 & 13.0 & 0.9 & 20.5 & 2366 & 42.1 \\
\hline & & 8 & 1.0 & 55 & 0.64 & 44.1 & 176 & 320 & 804 & 1057 & & & \begin{tabular}{|l|}
0.061 \\
\end{tabular} & 0.069 & 0.065 & 120 & 180 & 150 & 5.5 & 0.2 & 20.3 & 2388 & 42.5 \\
\hline & & 21 & 4.5 & 55 & 0.54 & \begin{tabular}{|l|}
47.9 \\
\end{tabular} & 196 & 356 & 793 & \begin{tabular}{|l|}
892 \\
\end{tabular} & 0.045 & & \begin{tabular}{|l|}
0.214 \\
\end{tabular} & 0.228 & 0.221 & 270 & 240 & 255 & 21.0 & 4.8 & 20.0 & 2227 & 32.0 \\
\hline 1 & $\mathrm{AE}$ 剂 & 15 & 4.5 & 55 & 0.62 & \begin{tabular}{|l|l|}
43.2 \\
\end{tabular} & 175 & 318 & 751 & 1024 & 0.045 & & \begin{tabular}{|l|}
0.161 \\
\end{tabular} & 0.152 & 0.157 & 240 & 240 & 240 & 15.0 & 4.8 & 20.0 & 2264 & 35.2 \\
\hline & & 8 & 4.5 & 55 & 0.64 & \begin{tabular}{|l|}
43.0 \\
\end{tabular} & 162 & 294 & 771 & 1057 & 0.045 & & \begin{tabular}{|l|}
0.096 \\
\end{tabular} & 0.072 & 0.084 & 180 & 210 & 195 & 8.0 & 4.7 & 20.5 & 2286 & 36.8 \\
\hline & & 21 & 4.5 & 55 & 0.54 & \begin{tabular}{|l|}
49.3 \\
\end{tabular} & 185 & 337 & 836 & 892 & 0.250 & & \begin{tabular}{|l|}
0.223 \\
\end{tabular} & 0.279 & 0.251 & 270 & 300 & 285 & 22.0 & 4.1 & 20.0 & 2279 & 38.2 \\
\hline & $\mathrm{AE}$ 減水剈 & 15 & 4.5 & 55 & 0.62 & \begin{tabular}{|l|l|}
44.3 \\
\end{tabular} & 166 & 302 & 787 & 1024 & 0.250 & & \begin{tabular}{|l|}
0.106 \\
\end{tabular} & 0.148 & 0.127 & 210 & 270 & 240 & 14.0 & 4.6 & 20.0 & 2287 & 37.4 \\
\hline & & 8 & 4.5 & 55 & 0.64 & 44.0 & 154 & 280 & 803 & 1057 & 0.250 & 0.0 & \begin{tabular}{|l|}
0.162 \\
\end{tabular} & 0.135 & 0.149 & 300 & 270 & 285 & 9.0 & 4.6 & 20.0 & 2293 & 35.3 \\
\hline & & 15 & $\begin{array}{ll}1.0 \\
\end{array}$ & $\overline{555}$ & 0.62 & 44.1 & 190 & 345 & $\begin{array}{ll}779 \\
\end{array}$ & 1024 & & & 0.267 & 0.319 & "0.293 & 210 & 180 & 195 & $\begin{array}{l}15.8 \\
\end{array}$ & 0.4 & 20.0 & 2347 & 40.5 \\
\hline & & 15 & 1.0 & 55 & 0.62 & \begin{tabular}{|l|l|}
44.1 \\
\end{tabular} & 190 & 345 & 779 & 1024 & & & \begin{tabular}{|l}
0.229 \\
\end{tabular} & 0.275 & 0.252 & \begin{tabular}{|l|}
180 \\
\end{tabular} & 210 & 195 & 15.0 & 0.4 & 21.0 & 2340 & 41.1 \\
\hline & & \begin{tabular}{|l|}
15 \\
\end{tabular} & 1.0 & 55 & 0.62 & \begin{tabular}{|l|}
44.1 \\
\end{tabular} & 190 & 345 & 779 & 1024 & & & \begin{tabular}{|l}
0.273 \\
\end{tabular} & 0.241 & 0.257 & 180 & 210 & \begin{tabular}{|l|}
195 \\
\end{tabular} & 16.2 & 0.5 & 21.0 & \begin{tabular}{|l|}
2337 \\
\end{tabular} & 38.7 \\
\hline & プレーン & \begin{tabular}{|l|}
15 \\
\end{tabular} & 1.0 & 55 & 0.62 & \begin{tabular}{|l|}
44.1 \\
\end{tabular} & 190 & 345 & 779 & 1024 & & & \begin{tabular}{|l|}
0.225 \\
\end{tabular} & 0.237 & 0.231 & 180 & 180 & 180 & \begin{tabular}{|l|}
16.7 \\
\end{tabular} & 0.3 & 21.5 & 2340 & 41.4 \\
\hline & & 15 & 1.0 & 55 & 0.62 & \begin{tabular}{|l|}
44.1 \\
\end{tabular} & 190 & 345 & 779 & 1024 & & & \begin{tabular}{|l|}
0.325 \\
\end{tabular} & 0.226 & 0.276 & 210 & 180 & 195 & 14.5 & 0.5 & 21.0 & 2333 & 40.5 \\
\hline & & \begin{tabular}{|l|}
15 \\
\end{tabular} & 1.0 & 55 & 0.62 & \begin{tabular}{|l|l|}
44.1 \\
\end{tabular} & \begin{tabular}{|l|}
190 \\
\end{tabular} & 345 & 779 & 1024 & & & \begin{tabular}{|l|l|}
0.223 \\
\end{tabular} & 0.220 & 0.222 & 210 & 210 & \begin{tabular}{|l|}
210 \\
\end{tabular} & 15.6 & 0.0 & 21.5 & 2345 & 38.7 \\
\hline & & 15 & 1.0 & 55 & 0.62 & \begin{tabular}{|l|l|}
44.1 \\
\end{tabular} & \begin{tabular}{|l|}
190 \\
\end{tabular} & 345 & 779 & \begin{tabular}{|l|}
1024 \\
\end{tabular} & & & \begin{tabular}{|l|}
0.230 \\
\end{tabular} & 0.264 & 0.247 & \begin{tabular}{|l|}
210 \\
\end{tabular} & 240 & \begin{tabular}{|l|}
225 \\
\end{tabular} & \begin{tabular}{|l|}
17.2 \\
\end{tabular} & 0.2 & 20.0 & \begin{tabular}{|l|}
2341 \\
\end{tabular} & 44.3 \\
\hline & & \begin{tabular}{|l|}
15 \\
\end{tabular} & 4.5 & 55 & 0.62 & \begin{tabular}{|l|}
43.2 \\
\end{tabular} & 175 & 318 & 751 & 1024 & 0.040 & & 0.222 & 0.198 & 0.210 & 240 & 240 & \begin{tabular}{|l|}
240 \\
\end{tabular} & \begin{tabular}{|l|}
17.1 \\
\end{tabular} & 5.8 & 20.0 & 2248 & 26.2 \\
\hline & & 15 & 4.5 & 55 & 0.62 & 43.2 & 175 & 318 & 751 & 1024 & 0.040 & & 0.245 & 0.263 & 0.254 & 210 & 21 & 210 & 16.4 & 5.4 & 21.0 & 2250 & 25.7 \\
\hline & & \begin{tabular}{|l|}
15 \\
\end{tabular} & 4.5 & 55 & 0.62 & \begin{tabular}{|l|}
43.2 \\
\end{tabular} & 175 & 318 & 751 & 1024 & 0.040 & & \begin{tabular}{|l}
0.192 \\
\end{tabular} & 0.165 & 0.179 & 210 & 210 & 210 & 15.5 & 5.9 & 21.0 & 2252 & 26.6 \\
\hline 2 & $\mathrm{AE}$ 剂 & \begin{tabular}{|l|}
15 \\
\end{tabular} & 4.5 & 55 & 0.62 & \begin{tabular}{|l|}
43.2 \\
\end{tabular} & 175 & 318 & 751 & 1024 & 0.040 & & \begin{tabular}{|l|}
0.188 \\
\end{tabular} & 0.176 & 0.182 & \begin{tabular}{|l|}
210 \\
\end{tabular} & 180 & \begin{tabular}{|l|}
195 \\
\end{tabular} & \begin{tabular}{|l|}
18.0 \\
\end{tabular} & 5.2 & 21.5 & 2251 & 29.0 \\
\hline & & 15 & 4.5 & 55 & 0.62 & \begin{tabular}{|l|}
43.2 \\
\end{tabular} & 175 & 318 & 751 & 1024 & 0.040 & & \begin{tabular}{|l|}
0.192 \\
\end{tabular} & 0.180 & 0.186 & 210 & 210 & 210 & 15.2 & 5.1 & 21.5 & 2257 & 24.6 \\
\hline & & \begin{tabular}{|l|}
15 \\
\end{tabular} & 4.5 & 55 & 0.62 & 43.2 & 175 & 318 & 751 & 1024 & 0.040 & & \begin{tabular}{|l|}
0.231 \\
\end{tabular} & 0.224 & 0.228 & 210 & 21 & 210 & 16.9 & 4.6 & 22.0 & 2266 & 20.9 \\
\hline & & 15 & 4.5 & 55 & 0.62 & \begin{tabular}{|l|l|}
43.2 \\
\end{tabular} & 175 & 318 & 751 & \begin{tabular}{|l|}
1024 \\
\end{tabular} & 0.040 & & \begin{tabular}{|l|}
0.177 \\
\end{tabular} & 0.203 & 0.190 & \begin{tabular}{|l|}
210 \\
\end{tabular} & 210 & \begin{tabular}{|l|}
210 \\
\end{tabular} & 15.0 & 4.6 & 20.0 & \begin{tabular}{|l|}
2266 \\
\end{tabular} & 24.6 \\
\hline & & \begin{tabular}{|l|}
15 \\
\end{tabular} & 4.5 & 55 & 0.62 & \begin{tabular}{|l|l|}
44.3 \\
\end{tabular} & 166 & 302 & 787 & \begin{tabular}{|l|}
1024 \\
\end{tabular} & 0.250 & 0.006 & 0.217 & 0.231 & 0.224 & 270 & 270 & \begin{tabular}{|l|}
270 \\
\end{tabular} & \begin{tabular}{|l|}
14.7 \\
\end{tabular} & 5.0 & 20.0 & 2271 & 31.4 \\
\hline & & 15 & 4.5 & 55 & 0.62 & 44. & 166 & 302 & 787 & 1024 & 0.250 & 0.006 & \begin{tabular}{|l|}
0.190 \\
\end{tabular} & 97 & 0.194 & 240 & 240 & \begin{tabular}{|l|}
240 \\
\end{tabular} & 15.6 & 8 & 21.0 & 2216 & 29.9 \\
\hline & & \begin{tabular}{|l|}
15 \\
\end{tabular} & 4.5 & 55 & 0.62 & 44.3 & 166 & 302 & 787 & 1024 & 0.250 & 0006 & 0.202 & 0.200 & 0.201 & 240 & 240 & 240 & 17.0 & 5.9 & 21.0 & 2257 & 34.0 \\
\hline & $\mathrm{AE}$ 減水㓮 & \begin{tabular}{|l|}
15 \\
\end{tabular} & 4.5 & 55 & 0.62 & \begin{tabular}{|l|}
44.3 \\
\end{tabular} & 166 & 302 & 787 & 1024 & 0.250 & 0.006 & 0.217 & 0.190 & 0.204 & 210 & 240 & 225 & \begin{tabular}{|l|}
17.7 \\
\end{tabular} & 3.9 & 21.5 & \begin{tabular}{|l|}
2289 \\
\end{tabular} & 34.6 \\
\hline & & 15 & 4.5 & 55 & 0.62 & 44. & 166 & 302 & 787 & 1024 & 0.250 & & \begin{tabular}{|l|}
0.184 \\
\end{tabular} & 0.1 & 0.186 & 210 & 21 & \begin{tabular}{|l|}
210 \\
\end{tabular} & 16.4 & 4.3 & 21.5 & \begin{tabular}{|l|}
2253 \\
\end{tabular} & 34.4 \\
\hline & & 15 & 4.5 & 55 & .62 & 44.8 & \begin{tabular}{|l|}
166 \\
\end{tabular} & 302 & 787 & \begin{tabular}{|l|}
1024 \\
\end{tabular} & 0.250 & & 0.237 & 0.2 & 0.249 & 270 & 270 & 270 & 16.4 & 4.9 & 21.0 & 2272 & 33.7 \\
\hline & & 15 & 4.5 & 55 & 0.62 & 44.3 & 166 & 302 & 787 & 1024 & 0. & & 0.228 & 0.233 & 0.231 & 240 & 240 & 240 & 15.0 & 5.0 & 19.5 & 2265 & 34.3 \\
\hline & & \begin{tabular}{|l|}
21 \\
\end{tabular} & 1.0 & 45 & 0.54 & \begin{tabular}{|l|l|}
46.4 \\
\end{tabular} & 213 & 473 & 744 & \begin{tabular}{|l|}
892 \\
\end{tabular} & & & \begin{tabular}{|l|}
0.231 \\
\end{tabular} & & & 210 & & & 21.0 & \begin{tabular}{|l|l}
0.9 \\
\end{tabular} & 20.0 & \begin{tabular}{|l|}
2198 \\
\end{tabular} & 56.5 \\
\hline & プレーン & 15 & 1.0 & 45 & 0.62 & 42.0 & 190 & 422 & 717 & 1024 & & & \begin{tabular}{|l|}
0.187 \\
\end{tabular} & & & 180 & & & \begin{tabular}{|l|}
16.3 \\
\end{tabular} & 0.5 & 21.0 & \begin{tabular}{|l|}
2225 \\
\end{tabular} & 57.8 \\
\hline & & 8 & 1.0 & 45 & 0.64 & 42.2 & 176 & 391 & 746 & 1057 & & & \begin{tabular}{|l|}
0.150 \\
\end{tabular} & & & 180 & & & 9.5 & 0.9 & 21.5 & 2222 & 55.4 \\
\hline & & \begin{tabular}{|l|}
21 \\
\end{tabular} & 4.5 & 45 & 0.54 & 45.8 & 196 & 435 & 729 & 892 & 0.040 & & \begin{tabular}{|l|}
0.191 \\
\end{tabular} & & & 210 & & & 20.0 & 5.0 & 20.5 & \begin{tabular}{|l|}
2123 \\
\end{tabular} & 42.9 \\
\hline & $\mathrm{AE}$ 剂 & \begin{tabular}{|l|}
15 \\
\end{tabular} & 4.5 & 45 & 0.62 & \begin{tabular}{|l|}
41.2 \\
\end{tabular} & 175 & 388 & 694 & 1024 & \begin{tabular}{|l|}
0.040 \\
\end{tabular} & & \begin{tabular}{|l|}
0.142 \\
\end{tabular} & & & 210 & & & \begin{tabular}{|l|}
15.1 \\
\end{tabular} & 5.9 & 21.0 & 2119 & 41.3 \\
\hline & & 8 & 4.5 & 45 & 0.64 & 41.3 & 162 & 360 & 718 & \begin{tabular}{|l|}
1057 \\
\end{tabular} & \begin{tabular}{|l|}
0.040 \\
\end{tabular} & & \begin{tabular}{|l|}
0.119 \\
\end{tabular} & & & 180 & & & 7.9 & 4.6 & 21.0 & 2161 & 42.6 \\
\hline & & \begin{tabular}{|l|}
21 \\
\end{tabular} & 4.5 & 45 & 0.54 & \begin{tabular}{|l|l|}
47.4 \\
\end{tabular} & 185 & 412 & 776 & 892 & 0.250 & & 0.254 & & & 270 & & & 20.3 & 4.4 & 21.0 & 2142 & 45.1 \\
\hline & AE減水剂 | & 15 & 4.5 & 45 & 0.62 & 42.5 & 166 & 369 & 732 & 1024 & 0.250 & 0.006 & \begin{tabular}{|l|}
0.186 \\
\end{tabular} & & & 270 & & & \begin{tabular}{|l|}
16.1 \\
\end{tabular} & 4.7 & 20.0 & 2153 & 40.7 \\
\hline & & 8 & 4.5 & 4 & 0.6 & 42 & 154 & 342 & 753 & 1057 & \begin{tabular}{|l|}
0.250 \\
\end{tabular} & & \begin{tabular}{|l|}
0.148 \\
\end{tabular} & & & 240 & & & 7.4 & 3.6 & 21.0 & \begin{tabular}{|l|}
2179 \\
\end{tabular} & 41.6 \\
\hline & & \begin{tabular}{|l|}
21 \\
\end{tabular} & 1.0 & 55 & 0.54 & \begin{tabular}{|l|}
48.6 \\
\end{tabular} & 213 & 387 & 814 & \begin{tabular}{|l|}
892 \\
\end{tabular} & & & \begin{tabular}{|l|}
0.466 \\
\end{tabular} & & & 240 & & & 22.5 & 0.0 & 20.0 & \begin{tabular}{|l|}
2197 \\
\end{tabular} & 34.0 \\
\hline & プレーン & 15 & 1.0 & 55 & 0.62 & \begin{tabular}{|l|l|}
44.1 \\
\end{tabular} & 190 & 345 & 779 & \begin{tabular}{|l|}
1024 \\
\end{tabular} & & & 0.323 & & & 240 & & & \begin{tabular}{|l|}
17.0 \\
\end{tabular} & 0.1 & 19.0 & 2215 & 45.1 \\
\hline & & 8 & 1.0 & 55 & 0.64 & 44.1 & 176 & 320 & 804 & 1057 & & & 0.223 & & & 180 & & & 8.0 & 0.4 & 19.0 & 2221 & 43.5 \\
\hline & & \begin{tabular}{|l|}
21 \\
\end{tabular} & 4.5 & 55 & 0.54 & 47.9 & 196 & 356 & 793 & \begin{tabular}{|l|}
892 \\
\end{tabular} & 0.040 & & 0.311 & & & 300 & & & \begin{tabular}{|l|}
20.2 \\
\end{tabular} & 4.5 & 21.0 & 2113 & 34.5 \\
\hline 3 & $\mathrm{AE}$ 郕 & 15 & 4.5 & 55 & 0.62 & \begin{tabular}{|l|l|}
43.2 \\
\end{tabular} & 175 & 318 & 751 & 1024 & 0.040 & & 0.231 & & & 270 & & & 17.0 & 5.3 & 20.5 & 2104 & 30.7 \\
\hline & & 8 & 4.5 & 55 & 0.64 & 43.0 & 162 & 294 & 771 & 1057 & 0.040 & & \begin{tabular}{|l|}
0.167 \\
\end{tabular} & & & 180 & & & \begin{tabular}{|l|}
9.5 \\
\end{tabular} & 5.1 & 21.0 & 2140 & 28.0 \\
\hline & & \begin{tabular}{|l|}
21 \\
\end{tabular} & 4.5 & 55 & 0.54 & \begin{tabular}{|l|}
49.3 \\
\end{tabular} & 185 & 337 & 836 & 892 & \begin{tabular}{|l|}
0.250 \\
\end{tabular} & & \begin{tabular}{|l|}
0.323 \\
\end{tabular} & & & 240 & & & 21.6 & 3.8 & 21.0 & \begin{tabular}{|l|}
2143 \\
\end{tabular} & 36.5 \\
\hline & AE減水剮 | & \begin{tabular}{|l|}
15 \\
\end{tabular} & 4.5 & 55 & 0.62 & \begin{tabular}{|l|l|}
44.3 \\
\end{tabular} & 166 & 302 & 787 & 1024 & 0.250 & & 0.220 & & & 240 & & & \begin{tabular}{|l|}
16.5 \\
\end{tabular} & 4.5 & 15.0 & 2150 & 35.8 \\
\hline & & 8 & 4.5 & 55 & 0.64 & 44.0 & 154 & 280 & 803 & \begin{tabular}{|l|}
1057 \\
\end{tabular} & 0.250 & & \begin{tabular}{|l|}
0.143 \\
\end{tabular} & & & 240 & & & 8.1 & 4.0 & 20.5 & \begin{tabular}{|l|}
2162 \\
\end{tabular} & 34.8 \\
\hline & & \begin{tabular}{|l|}
21 \\
\end{tabular} & 1.0 & 65 & 0.54 & 50.0 & 213 & 328 & 862 & 892 & & & 0.486 & & & 240 & & & 22.5 & 0.5 & 20.0 & 2185 & 31.1 \\
\hline & プレーン & \begin{tabular}{|l|}
15 \\
\end{tabular} & 1.0 & 65 & 0.62 & 45.4 & 190 & 292 & 822 & \begin{tabular}{|l|}
1024 \\
\end{tabular} & & & \begin{tabular}{|l|}
0.387 \\
\end{tabular} & & & 240 & & & 14.6 & 0.8 & 20.0 & 2198 & 29.4 \\
\hline & & \begin{tabular}{|l|}
8 \\
\end{tabular} & 1.0 & 65 & \pm & 45.3 & 176 & 271 & 844 & 1057 & & & \begin{tabular}{|l|}
0.262 \\
\end{tabular} & & & 180 & & & 8.1 & 0.5 & 20.0 & 2214 & 29.2 \\
\hline & & \begin{tabular}{|l|}
21 \\
\end{tabular} & 4.5 & 65 & 0.54 & \begin{tabular}{|l|l|}
49.3 \\
\end{tabular} & 196 & 301 & 838 & 892 & \begin{tabular}{|l|}
0.040 \\
\end{tabular} & & 0.350 & & & 210 & & & \begin{tabular}{|l|}
20.2 \\
\end{tabular} & 5.8 & 20.0 & 2095 & 22.3 \\
\hline & $\mathrm{AE}$ 剂 & \begin{tabular}{|l|}
15 \\
\end{tabular} & 4.5 & 65 & 0.62 & 44.4 & 175 & 269 & 791 & 1024 & 0.040 & & \begin{tabular}{|l|}
0.344 \\
\end{tabular} & & & 240 & & & \begin{tabular}{|l|}
16.6 \\
\end{tabular} & 3.4 & 19.5 & 2152 & 26.5 \\
\hline & & 8 & 4.5 & 65 & 0.64 & \begin{tabular}{|l|}
44.2 \\
\end{tabular} & 162 & 249 & 808 & \begin{tabular}{|l|}
1057 \\
\end{tabular} & \begin{tabular}{|l|l|}
0.040 \\
\end{tabular} & & \begin{tabular}{|l|}
0.181 \\
\end{tabular} & & & 180 & & & 7.6 & 4.3 & 20.0 & \begin{tabular}{|l|}
2143 \\
\end{tabular} & 25.5 \\
\hline & & \begin{tabular}{|l|}
21 \\
\end{tabular} & 4.5 & 65 & 0.54 & 50.5 & 185 & 285 & 878 & 892 & 0.250 & 0.004 & \begin{tabular}{|l|}
0.347 \\
\end{tabular} & & & 240 & & & \begin{tabular}{|l|}
20.6 \\
\end{tabular} & 4.5 & 20.0 & \begin{tabular}{|l|}
2120 \\
\end{tabular} & 26.9 \\
\hline & $\mathrm{AE}$ 減水骫 & 15 & 4.5 & 65 & 0.62 & 45.5 & 166 & 255 & 824 & 1024 & 0.250 & 0.006 & \begin{tabular}{|l|}
0.301 \\
\end{tabular} & & & 240 & & & 15.5 & 4.5 & 20.0 & \begin{tabular}{|l|}
2137 \\
\end{tabular} & 30.7 \\
\hline & & 8 & 4.5 & 65 & 0.64 & 45.1 & 154 & 237 & 838 & 1057 & 0.250 & 0.006 & 0.185 & & & 210 & & & 7.6 & 3.9 & 20.0 & 2160 & 28.6 \\
\hline & L-ン & 15 & 4.5 & 55 & 0.62 & 444.1 & 190 & 345 & 7779 & 01024 & & 4 & $\begin{array}{l}\text { ※1:4行 } \\
\end{array}$ & 下参照 & $1 \overline{16}$ & ※4:41 & 下竝 & 240 & 19.9 & 1.2 & 18.5 & 2273 & 42.4 \\
\hline & $\mathrm{AE}$ 郕 & \begin{tabular}{|l|}
15 \\
\end{tabular} & 4.5 & 55 & 0.62 & \begin{tabular}{|l|l|}
43.2 \\
\end{tabular} & 175 & 318 & 751 & \begin{tabular}{|l|}
1024 \\
\end{tabular} & \begin{tabular}{|l|l|}
0.040 \\
\end{tabular} & & ※2:4行 & 下参照 & \begin{tabular}{|l|}
0.266 \\
\end{tabular} & $※ 5: 41$ & 㧁照 & \begin{tabular}{|l|}
266 \\
\end{tabular} & 16.5 & \begin{tabular}{|l}
5.9 \\
\end{tabular} & 20.0 & \begin{tabular}{|l|}
2195 \\
\end{tabular} & 33.2 \\
\hline & \begin{tabular}{|l|}
$\mathrm{AE}$ 減水剂 \\
\end{tabular} & 15 & 4.5 & 55 & 0.62 & 44.3 & 166 & 302 & 787 & 1024 & 0.250 & 0.006 & ※3:4行 & 下参照 & 0.280 & $※ 6: 44$ & 下参照 & 300 & 19.5 & 5.0 & 19.5 & 2215 & 31.7 \\
\hline 4 & 試料番号 & & 1 & 2 & 3 & 4 & 5 & 6 & 7 & & 試料番号 & & 1 & 2 & 3 & 4 & 5 & 6 & 7 & & & & \\
\hline & ブリーディン & $※ 1$ & 0.368 & 0.487 & 0.435 & 0.363 & 0.381 & 0.361 & 0.517 & & & $\% 4$ & 240 & 240 & 240 & 240 & 240 & 240 & 240 & & & & \\
\hline & グ量 & $※ 2$ & 0.251 & 0.278 & 0.293 & 0.271 & 0.254 & 0.254 & 0.261 & & & $※ 5$ & 270 & 270 & 270 & 270 & 270 & 270 & 240 & & & & \\
\hline & $\left(\mathrm{cm}^{3} / \mathrm{cm}^{2}\right)$ & $※ 3$ & 0.280 & 0.299 & 0.287 & 0.305 & 0.284 & 0.301 & 0.282 & & & $※ 6$ & 300 & 300 & 300 & 300 & 300 & 300 & 300 & & & & \\
\hline
\end{tabular}

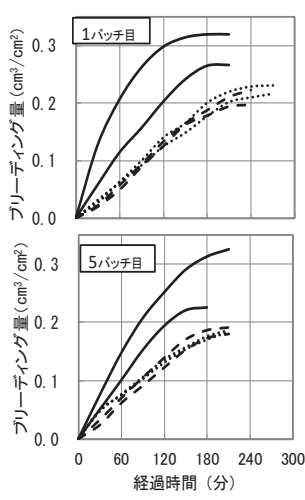

図 3
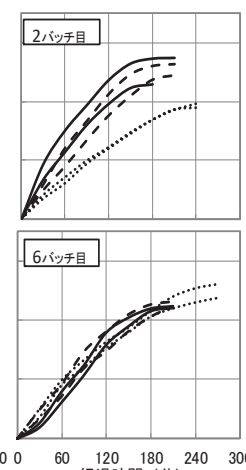

60 経通時間 (分)
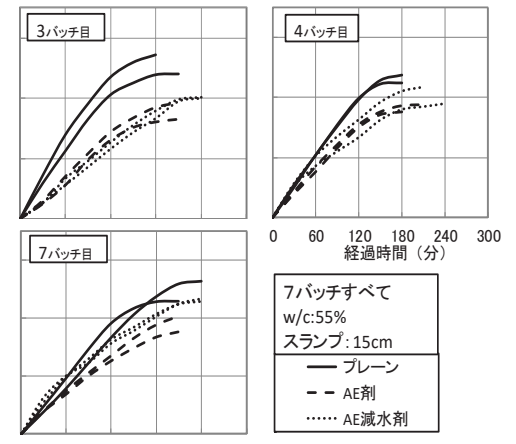

AE減水剂

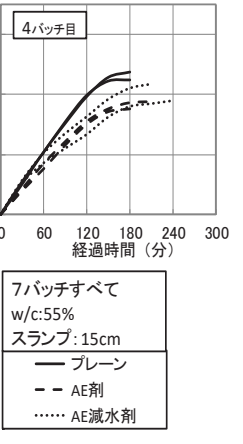

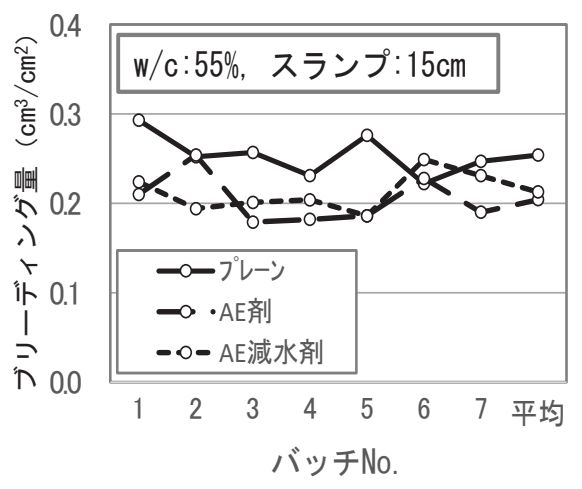

図 4 バッチ間のばらつき（実験 2 ） 
す。同じ日にプレーン、 $\mathrm{AE}$ 剂、 $\mathrm{AE}$ 減水剂を用いたコンクリートの 試験をそれぞれ 1 バッチずつ行っている。また、図 4 は各回のブリ ーディング量（2 回の平均）と 7 バッチの平均を示している。これ らによると、平均的には一般にいわれているプレーンコンクリート のほうが、 $\mathrm{AE}$ 剂や $\mathrm{AE}$ 減水剂を使用した場合よりブリーディング 量は大きくなっているが、試験を行った日によってはほぼ同等であ ったり、一部に逆転が見られたりしており、ブリーディング試験結 果にはバッチ間の影響がかなりあるものといえる。今回は一つの調 合の結果ではあるが、ブリーディング量の標準偏差 $\left(\mathrm{cm}^{3} / \mathrm{cm}^{2}\right)$ はそ れぞれ $0.023,0.026,0.021$ 、また、変動係数 $(\%)$ は $9.0,12.7,9.8$ と なった。これから推測すると、実験 1 は混和剤の種類ごとに試験を 行った日が異なるため、そのような結果となることも十分ありうる ものと考えられる。なお、十代田は、「コンクリートのブリーディン グ試験結果の大きなバラツキに悩まされることもなくなる」として モルタル分による試験を提案している ${ }^{9)}$ 。また、高畑らの行った水 セメント比 $55 \%$ 、スランプ $18 \mathrm{~cm}$ の $\mathrm{AE}$ 減水剤を使用したコンクリ ートのブリーディング試験結果 ${ }^{10)}$ をみると、同一調合について図か ら読み取ったブリーディング率を換算したブリーディング量 $\left(\mathrm{cm}^{3} / \mathrm{cm}^{2}\right)$ には、 $0.255,0.094,0.186$ とかなりのばらつきが認めら れることから、ブリーディング試験はもともとばらつきの大きい試 験であると考えられる。

\section{4 単位水量・水セメント比・混和剤の影響}

図 5 は、実験 3 のブリーディング試験結果を示したもので、図の 中央の水セメント比 $55 \%$ に比べて、左側の水セメント比 $45 \%$ はブ リーディング量が小さく、右側の水セメント比 $65 \%$ は大きくなる傾 向が確認された。図 6 は実験 3 の結果を単位水量とブリーディング 量の関係により示したものである。これによると、水セメント比お よび混和剤の種類にかかわらず、ほとんどの場合、単位水量が減少 するとブリーディング量も減少する傾向を示していることが確認さ れた。また、同一単位水量で比較すると、いずれの混和剤を使用し た場合も水セメント比が小さくなるとブリーディング量は減少する 傾向を示した。

\section{5 同一バッチ内のブリーディング量のばらつき}

実験 3 では同一バッチ内のばらつきが小さいと考えて 1 バッチに つき 1 回の試験を行ったが、それを確認するため、水セメント比 $55 \%$, スランプ $15 \mathrm{~cm}$ の同一バッチで 7 回試験を行った実験 4 の結 果を図 7 に示す。ばらつきの程度を比較しやすいように、 $\mathrm{AE}$ 剂と $\mathrm{AE}$ 減水剂を用いた場合は、縦軸の最大值をプレーンコンクリート の 0.6 に対して 0.4 としている。これによると、プレーンに対して $\mathrm{AE}$ 剂や $\mathrm{AE}$ 減水剂を使用した場合はばらつきが小さくなっている。 これは $\mathrm{AE}$ 㓮では独立した微細な空気泡をコンクリート中に一様に 含むことにより、また $\mathrm{AE}$ 減水剂ではそれに加えてセメント粒子の 分散効果により、プレーンコンクリートに比べて採取試料の構成材 料の分布が均質になったためと推察される。今回は一つの調合の結 果ではあるが、ブリーディング量の標準偏差 $\left(\mathrm{cm}^{3} / \mathrm{cm}^{2}\right)$ はそれぞれ 0.060, 0.014, 0.009、また、変動係数(\%)は 14.4, 5.4, 3.2 となった。

\section{5. 予測式の作成に関する検討}

\section{1 作成の方針}

既往の実験結果によると、同一水セメント比における単位水量と
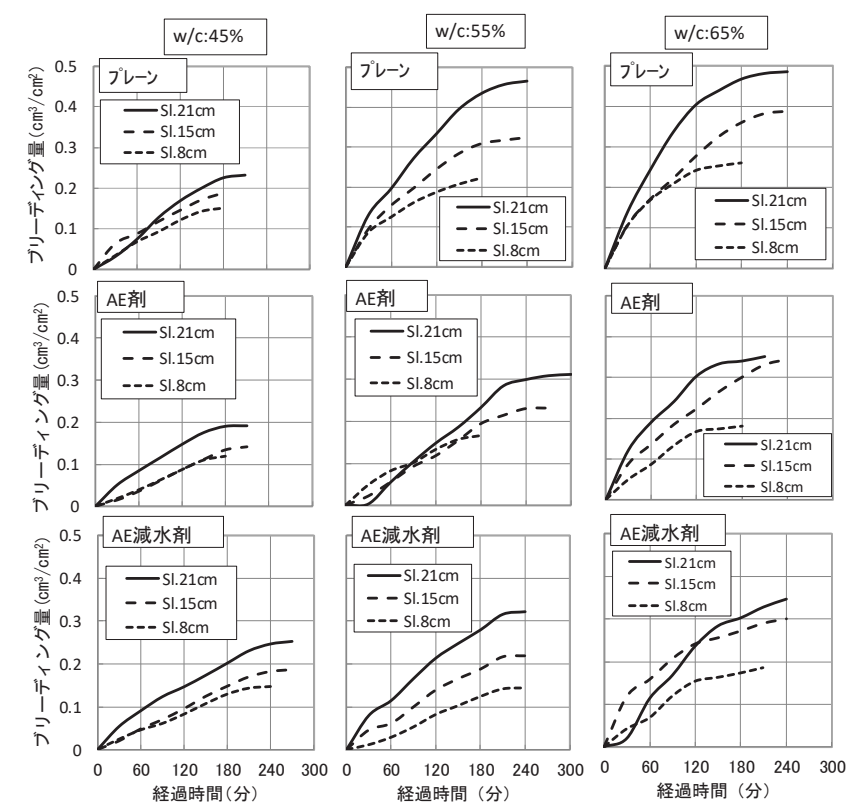

図 5 ブリーディング試験結果（実験 3 ）

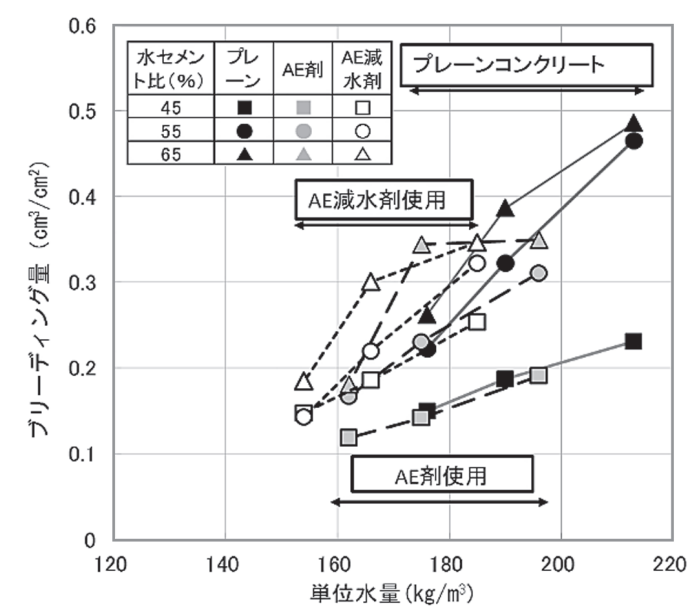

図 6 単位水量とブリーディング量の関係（実験 3 ）
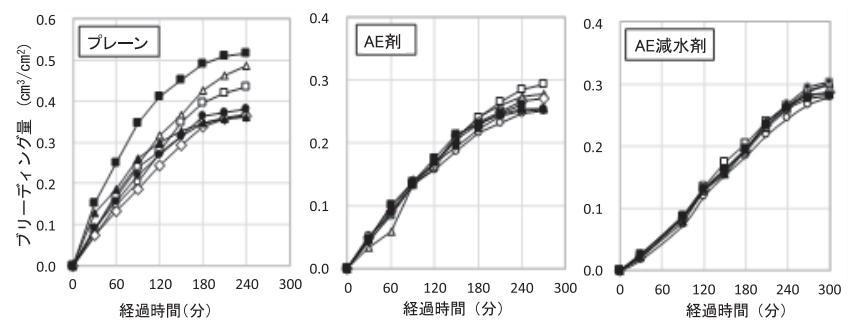

\section{図 7 同ーバッチ内のばらつき（実験 4)}

ブリーディング量の関係は、単位水量が広範囲にわたる場合には S 字曲線になると考えられる ${ }^{11)}$ が、図 6 に示した結果によると、一部 にばらつきは認められるものの、一般的なコンクリートの単位水量 の範囲では、同一水セメント比における単位水量とブリーディング 量の関係はほぼ直線になるとみなして差し支えないものと考えられ る。そして、この外扦した直線は $\mathrm{x}$ 軸上のほぼ同一の点に収束する 
ことが推測される。また、水セメント比が大きくなるとこの直線の 傾きは大きくなる傾向が認められる。このため、図 8 に示すように、 各コンクリートについて回帰式を求め、外挿により $\mathrm{x}$ 切片、寸なわ ちブリーディング量が 0 になるとみなされる単位水量を求め、次に 水セメント比と回帰式の傾き $\mathrm{a}$ との関係を求めて、ブリーディング 量を単位水量と水セメント比との関係で表示することとした。

\section{2 本実験結果による検討}

（1）単位水量とブリーディング量の関係に関する検討

同一水セメント比ごとに回帰式を外挿したときの $\mathrm{x}$ 切片の值を表 5 に示す。これによると $\mathrm{x}$ 切片の值は各コンクリートの水セメント比 および混和剤の種類によりあまり変わらないという結果になり、全 平均は $119 \mathrm{~kg} / \mathrm{m}^{3}$ となった。

\section{（2）水セメント比とブリーディング量の関係に関する検討}

次に、図 8 に示すように、各単位水量から表 5 の全平均である 119 を差し引いた值 $\mathrm{x}^{\prime}$ 用いて、 $\mathrm{x}^{\prime}$ とブリーディング量の関係を原 点回帰したときの式の傾き $\mathrm{a}$ を求め、図 9 に水セメント比と回帰式 の傾き $\mathrm{a}$ の関係を示す。これによるとプレーンコンクリートに比べ て $\mathrm{AE}$ 剂を使用したコンクリートはやや小さく、また、 $\mathrm{AE}$ 減水剂 を使用したコンクリートはやや大きくなる傾向が認められた。ここ では、プレーンコンクリートと $\mathrm{AE}$ 減水剂を使用したコンクリート の両者の平均として、ブリーディングが 0 となる水セメント比を $23.2 \%$ とした。これは T.C.Powers の基本水セメント比に相当する もので、彼は $25 \%$ 、梶井らは $30 \%$ としており ${ }^{14)}$ 、それらよりやや 小さい值となった。一方、 $\mathrm{AE}$ 減水剤を使用したコンクリートは全 般にプレーンコンクリートや $\mathrm{AE}$ 剂を使用したコンクリートより傾 き $\mathrm{a}$ の值が大きくなっているが、これは $\mathrm{AE}$ 減水剂の効果によりセ メント粒子がより分散されたことも一因と考えられる。 $\mathrm{AE}$ 減水剤 を使用したコンクリートの回帰式の $\mathrm{x}$ 切片は+2.6 でプレーンコン クリートや AE 剂を使用したコンクリートと異なっているが、式の 簡易化を図るため $\mathrm{x}$ 切片を一 -23.2 とし、水セメント比 $55 \%$ におけ る回帰式の傾き $\mathrm{a}$ の值を求めると、 $\mathrm{AE}$ 減水剤を使用した場合はプ レーンコンクリートや $\mathrm{AE}$ 剂を使用した場合の 1.19 倍となった。式 (1)は以上の結果をまとめたものである。

回帰式の係数 a

$$
\text { プレーンと } \mathrm{AE} \text { 剂 }: \mathrm{a}=0.0125 \times(\mathrm{w} / \mathrm{c}-23.2) / 100
$$

$\mathrm{AE}$ 減水剂： $\quad \mathrm{a}=0.0149 \times(\mathrm{w} / \mathrm{c}-23.2) / 100$

ブリーディング量の推定式

$$
\begin{aligned}
& \mathrm{B}=\mathrm{a}\left(\mathrm{W}-\mathrm{W}_{0}\right)=\alpha \quad\left(\mathrm{W}-\mathrm{W}_{0}\right)(\mathrm{w} / \mathrm{c}-23.2) / 100 \quad \cdots \cdot(1) \\
& \text { ここに、 } \mathrm{B}: \text { ブリーディング量 }\left(\mathrm{cm}^{3} / \mathrm{cm}^{2}\right)
\end{aligned}
$$

$\mathrm{W}$ : 単位水量 $\left(\mathrm{kg} / \mathrm{m}^{3}\right)$

$\mathrm{W}_{0}$ : 実験定数（本実験では 119）（kg/m³)

$\alpha$ : 実験定数(本実験ではプレーンと $\mathrm{AE}$ 剂 : 0.0125, $\mathrm{AE}$ 減水剂：0.0149)

\section{3 既往の実験結果による検討}

表 6 に、既往の実験結果で同一水セメント比における単位水量と ブリーディング量の関係が直線であるとみなして外挿により求めた ブリーディング量が 0 になる単位水量（表中の $\mathrm{x}$ 切片）を示す。

図 10 はこれを水セメント比との関係で示したもので、これによる と、本実験で得られた值は、プレーンコンクリート、 $\mathrm{AE}$ 剂を使用

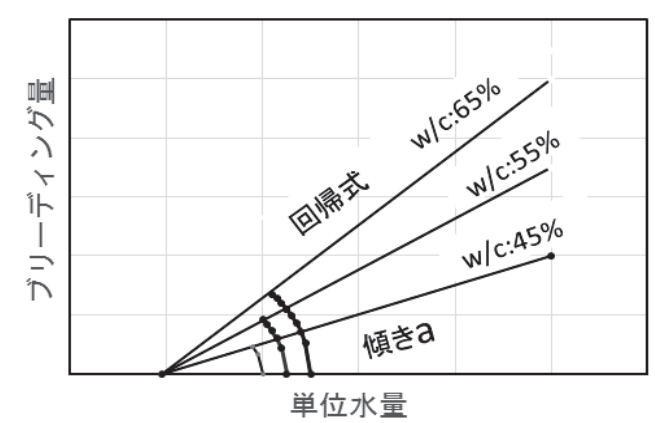

図 8 回帰式の傾き a を求める模式図

表 5 回帰式を外挿したときの $x$ 切片

\begin{tabular}{|c||c|c|c|}
\hline 水セメント比 $(\%)$ & プレーン & $\mathrm{AE} \mathrm{A}_{\mathrm{A}}$ & $\mathrm{AE}$ 減水剤 \\
\hline \hline 45 & 104 & 109 & 112 \\
\hline 55 & 142 & 121 & 128 \\
\hline 65 & 128 & 114 & 112 \\
\hline \hline 平均 & 125 & 115 & 117 \\
\hline 全平均 & \multicolumn{3}{|c|}{119} \\
\hline
\end{tabular}

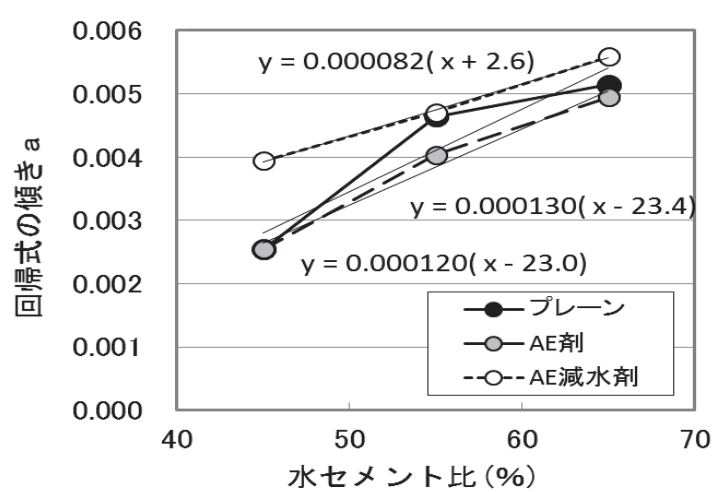

図 9 水セメント比と回帰式の傾き a の関係

したコンクリートおよび $\mathrm{AE}$ 減水剂を使用したコンクリートのいず れにおいてもほぼ平均的な值とみなして差し支えないものと考えら れる。なお、文献 12 と 25 の減水剂は $\mathrm{AE}$ 減水剂とみなした。

また、表 7 には既往の実験結果から同様にして求めたブリーディ ングが 0 になる水セメント比を示し、図 11 にはそれを単位水量と の関係で示す。かなりばらつきがあり、本実験から得られた值はブ レーンと $\mathrm{AE}$ 減水剤を使用した場合ではやや小さい值となった。実 験 3 の実験值とこの式より求めた計算值の関係を示すと図 12 のよ うになり、計算值は実験值の $\pm 25 \%$ 以内となった。

\section{6. 本実験における各実験の比較}

これまで行った 4 つの実験のうち、共通の調合である w/c55\%, ス ランプ $15 \mathrm{~cm}$ の場合をまとめて示すと図 13 のようになる。この図 からわかるように、実験 2 と実験 3 は同じロットのセメントと細骨 材を使用しているため、類似の結果となったが、実験 1 と実験 4 は それと異なる結果となっており、これはそれぞれセメントと細骨材 のロットが異なるためと推測される。このため、実験 3 で求めた実 験定数 $\alpha$ をそのまま適用しても実験值と計算值の対応は図 14 に示 すように良くなく、 $\pm 25 \%$ 範囲を大きく外れることとなった。こ のため、以後の検討では、その実験に対応して実験定数 $\alpha$ を求めて 本実験の式を適用することとした。 


\begin{tabular}{|c|c|c|c|c|c|c|c|c|c|c|c|c|c|c|c|}
\hline \multirow{3}{*}{$\begin{array}{l}\text { 発 } \\
\text { 表 } \\
\text { 年 }\end{array}$} & \multirow{3}{*}{ 著者 } & \multicolumn{4}{|c|}{ 使用材料 } & \multirow{3}{*}{$\begin{array}{l}\text { デ } \\
\text { タ } \\
\text { 数 }\end{array}$} & \multicolumn{5}{|c|}{ 調合 } & \multicolumn{3}{|c|}{ 回帰式 } & \multirow{3}{*}{ 備考 } \\
\hline & & \multirow{2}{*}{ セメント } & \multirow{2}{*}{ 細骨材 } & \multirow{2}{*}{ 粗骨材 } & \multirow{2}{*}{ 混和㨈 } & & \multirow{2}{*}{$\begin{array}{l}\text { 水セメ } \\
\text { 屁 } \\
(\%)\end{array}$} & \multicolumn{2}{|c|}{$\begin{array}{c}\text { 単位水量 } \\
\left(\mathrm{kg} / \mathrm{m}^{3}\right)\end{array}$} & \multicolumn{2}{|c|}{$\begin{array}{c}\text { スランプ } \\
(\mathrm{cm})\end{array}$} & \multirow{2}{*}{$\begin{array}{c}\text { 傾き } \\
(\times \\
\left.10^{-3}\right)\end{array}$} & \multirow{2}{*}{$\begin{array}{c}\mathrm{y} \\
\text { 切片 }\end{array}$} & \multirow{2}{*}{$\begin{array}{c}\mathrm{x} \\
\text { 切片 }\end{array}$} & \\
\hline & & & & & & & & 最小 & 最大 & 最小 & 最大 & & & & \\
\hline \multirow{11}{*}{1956} & \multirow{11}{*}{ 西他 ${ }^{12)}$} & \multirow{12}{*}{ 普通术 } & & & & 7 & 55.0 & 165 & 220 & 10.0 & 22.0 & 2.47 & -0.278 & 113 & \\
\hline & & & & & プレン & 7 & 65.0 & 186 & 224 & 10.0 & 22.0 & 2.78 & -0.336 & 121 & \\
\hline & & & 砂 $0.6 \mathrm{~mm}$ & 砂利 $25 \mathrm{~mm}$ & $\mathrm{~A} \mathrm{E} \boldsymbol{x}_{1}$ & 4 & 50.0 & 168 & 195 & 10.0 & 22.0 & 2.33 & -0.292 & 125 & \\
\hline & & & 砂 $0.6 \mathrm{~mm}$ & 砂机25mm & AE们 & 4 & 60.0 & 165 & 201 & 10.0 & 22.0 & 3.02 & -0.347 & 115 & \\
\hline & & & & & 減水剂 & 4 & 55.0 & 154 & 200 & 10.0 & 22.0 & 1.96 & -0.180 & 92 & \\
\hline & & & & & 減水㶡 & 4 & 65.0 & 160 & 192 & 10.0 & 22.0 & 3.88 & -0.408 & 105 & $150 \varphi \times 300 \sigma$ \\
\hline & & & & & & 7 & 55.0 & 173 & 198 & 10.0 & 22.0 & 2.26 & -0.228 & 101 & 容器使用 \\
\hline & & & & & 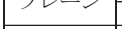 & 7 & 65.0 & 172 & 201 & 10.0 & 22.0 & 3.96 & -0.509 & 128 & \\
\hline & & & 砂 $2.5 \mathrm{~mm}$ & 山砂利 & $\mathrm{AE}$ 剂 & 4 & 50.0 & 150 & 192 & 10.0 & 22.0 & 1.38 & -0.161 & 117 & \\
\hline & & & (1) 2.011111 & $25 \mathrm{~mm}$ & AE们 & 4 & 60.0 & 151 & \begin{tabular}{|l|}
187 \\
\end{tabular} & 10.0 & 22.0 & 1.74 & -0.141 & 81 & \\
\hline & & & & & 減水剂 & 4 & 55.0 & 145 & 175 & 10.0 & 22.0 & 0.19 & 0.052 & - & \\
\hline & & & & & 诚皮制 & 4 & 65.0 & 163 & 185 & 10.0 & 22.0 & 4.96 & -0.706 & 142 & \\
\hline & & & 浜砂 $0.6 \mathrm{~mm}$ & & & 12 & 60.0 & 178 & 259 & 8.0 & 22.9 & 5.00 & -0.624 & 125 & $150 \varphi$ \\
\hline 1967 & 佐治他 ${ }^{13)}$ & 普通ポ & & 砂利 $25 \mathrm{~mm}$ & プレーン & \begin{tabular}{|r|}
6 \\
12
\end{tabular} & 70.0 & 179 & 269 & 14.5 & 22.9 & 4.85 & -0.484 & 100 & 容器を使用 \\
\hline & & & 川砂 $2.5 \mathrm{~mm}$ & & & \begin{tabular}{|r|r}
12 \\
6
\end{tabular} & $\begin{array}{l}60.0 \\
70.0\end{array}$ & $\begin{array}{l}168 \\
172\end{array}$ & \begin{tabular}{|l|}
242 \\
228 \\
\end{tabular} & $\begin{array}{l}8.5 \\
8.9\end{array}$ & $\begin{array}{l}20.9 \\
20.6\end{array}$ & $\frac{4.42}{4.65}$ & $\begin{array}{l}-0.539 \\
-0.621\end{array}$ & $\frac{122}{134}$ & 乙、沈降 \\
\hline & & & & & & 3 & 35.0 & 156 & 194 & 7.9 & 20.6 & 0.89 & -0.034 & 38 & \\
\hline 1970 & 根井 & 普通术 & 砂 $2.5 \mathrm{~mm}$ & 砂利 $25 \mathrm{~mm}$ & $\mathrm{AE}$ 剂 & 3 & 45.0 & 152 & 181 & 8.4 & 21.2 & 9.65 & -1.259 & 130 & \\
\hline & 娓开 & & & & & 3 & 55.0 & 148 & 177 & 8.7 & 21.9 & 9.35 & -1.000 & 107 & \\
\hline & & & & & & 3 & 65.0 & 148 & 177 & 7.8 & 20.8 & 6.68 & -0.493 & 74 & \\
\hline 1972 & 友澤仡 & 普通ポ & 川砂 $2.5 \mathrm{~mm}$ & 砕石 2005 & プレーン & 2 & 55.0 & 191 & 216 & 17.0 & 20.0 & 3.40 & -0.388 & 114 & \\
\hline & & & 川砂 $2.5 \mathrm{~mm}$ & 川砂利 & & $\frac{2}{2}$ & 65.0 & 188 & 214 & 14.0 & 22.0 & 15.5 & -1.772 & 114 & \\
\hline 1075 & & & 砕砂 2 & $25 \mathrm{~mm}$ & 剂 & $\frac{2}{2}$ & 65.0 & 161 & 186 & 8.5 & 18.5 & 3.12 & -0.382 & 122 & \\
\hline 1975 & 秋山他 ${ }^{16)}$ & 普通术 & \begin{tabular}{|l|} 
川砂 $2.5 \mathrm{~mm}$ \\
\end{tabular} & & $\mathrm{AE}$ 剂 & 2 & 65.0 & 165 & 190 & 9.0 & 19.2 & 3.69 & -0.480 & 130 & \\
\hline & & & 砕砂 $2.5 \mathrm{~mm}$ & 石 $25 \mathrm{~mm}$ & & $\frac{2}{2}$ & 65.0 & 176 & 197 & 8.5 & 18.8 & 4.02 & -0.564 & 140 & \\
\hline 1976 & 友澤他 ${ }^{17)}$ & 普通术 & 川砂 f.m.2.64 & 砕石 & $\mathrm{AE}$ 剂 & $\frac{2}{2}$ & $\begin{array}{l}65.0 \\
50.0\end{array}$ & 179 & \begin{tabular}{|l|}
198 \\
210
\end{tabular} & $\begin{array}{r}8.7 \\
121\end{array}$ & 19.2 & $\begin{array}{l}4.59 \\
388\end{array}$ & $\begin{array}{r}-0.671 \\
-0.621\end{array}$ & 146 & \\
\hline & & & 川砂 & 10 & & & & & & & & & & & \\
\hline 1978 & 十代田 ${ }^{18)}$ & 普通ポ & f.m.2.82 & F" 石 & プレーン & 4 & 61.0 & 157 & 213 & 6.0 & 20.5 & 1.20 & -0.093 & 78 & s/c絶対容積 \\
\hline & & & $\begin{array}{c}\text { 川砂 } \\
\text { f.m.1.66 }\end{array}$ & 砕石 $20 \mathrm{~mm}$ & & 3 & 61.0 & 176 & 213 & 14.0 & 21.0 & 1.62 & -0.153 & 94 & \\
\hline 1978 & 中川1 ${ }^{19)}$ & 普通ポ & 川砂 f.m.2.80 & 砂利 $20 \mathrm{~mm}$ & AE減水剤 & 2 & 60.0 & 157 & 174 & 8.5 & 18.5 & 2.59 & -0.132 & 51 & \\
\hline 1979 & 恢田他 20) & 普涌ポ & 川砂 & 砂利 $20 \mathrm{~mm}$ & A $\mathrm{A}$ 減水剂 & 2 & 60.0 & 171 & 185 & 20.0 & 22.0 & 4.29 & -0.343 & 80 & \\
\hline & 依田他 & & 川砂 & 砂利 $25 \mathrm{~mm}$ & AE減水凩 & 3 & 60.0 & 146 & 180 & 6.0 & 21.5 & 2.31 & -0.140 & 60 & \\
\hline 1981 & 池田他 (1) $^{21}$ & 普通ポ & 丘砂 & 砕石 $20 \mathrm{~mm}$ & AE減水剤 & 4 & 57.0 & 168 & $\mid 190$ & 12.0 & 20.5 & 2.21 & -0.251 & 114 & \\
\hline 1993 & 大分㫜生コン22) & 普通术 & 海砂＋山砂 & 矺石 $20 \mathrm{~mm}$ & AE減水剂 & 4 & 50.0 & 162 & 184 & 10.4 & 18.8 & 0.91 & 0.053 & - & \\
\hline 1993 & 大分県手 & & & 呼石 $20 \mathrm{~mm}$ & AE減水㸮 & 4 & 65.0 & 167 & 188 & 10.5 & 18.7 & 3.33 & -0.327 & 98 & \\
\hline 1997 & 松本他 ${ }^{23)}$ & 普通术 & 海砂＋山砂 & 砕石 $20 \mathrm{~mm}$ & AE減水剂 & 2 & 50.0 & 165 & \begin{tabular}{|l|}
189 \\
\end{tabular} & 8.0 & 19.5 & 2.08 & -0.284 & 137 & \\
\hline & & & & & & 2 & 65.0 & 163 & 187 & 8.0 & 19.5 & 3.75 & -0.541 & 144 & \\
\hline 2007 & 木村他 ${ }^{24)}$ & 普通ポ & 砕砂+砕砂 & 砕石 $20 \mathrm{~mm}$ & $\mathrm{AE}$ 減水剤 & 4 & 55.0 & 160 & 193 & 8.5 & 22.0 & 13.5 & -1.950 & 144 & \\
\hline
\end{tabular}

表 7 既往の実験結果から求めたブリーディングが ○になる水セメント比

\begin{tabular}{|c|c|c|c|c|c|c|c|c|c|c|c|c|c|c|c|c|c|}
\hline \multirow{3}{*}{$\begin{array}{l}\text { 発 } \\
\text { 表 } \\
\text { 年 }\end{array}$} & \multirow{3}{*}{ 著者 } & \multicolumn{4}{|c|}{ 使用材料 } & \multirow{3}{*}{\begin{tabular}{|l|}
$\vec{テ}$ \\
夕 \\
数 \\
\end{tabular}} & \multicolumn{7}{|c|}{ 調合 } & \multicolumn{3}{|c|}{ 回帰式 } & \multirow{3}{*}{ 備考 } \\
\hline & & \multirow[t]{2}{*}{ セメント } & \multirow[t]{2}{*}{ 細骨材 } & \multirow[t]{2}{*}{ 粗骨材 } & \multirow[t]{2}{*}{ 混和剤 } & & & $\begin{array}{l}\text { 风ント比 } \\
\%)\end{array}$ & \multicolumn{3}{|c|}{$\begin{array}{c}\text { 単位水量 } \\
\left(\mathrm{kg} / \mathrm{m}^{3}\right)\end{array}$} & \multicolumn{2}{|c|}{$\begin{array}{c}\begin{array}{c}\text { スランプ } \\
(\mathrm{cm})\end{array} \\
\end{array}$} & \multirow{2}{*}{$\begin{array}{c}\text { 傾き } \\
(\times \\
\left.10^{-3}\right) \\
\end{array}$} & \multirow[t]{2}{*}{ y切片 } & \multirow[t]{2}{*}{$x$ 切片 } & \\
\hline & & & & & & & \begin{tabular}{|l|} 
最小 \\
\end{tabular} & \begin{tabular}{|l|} 
最大 \\
\end{tabular} & 最小 & 平均 & \begin{tabular}{|l|} 
最大 \\
\end{tabular} & 最小 & \begin{tabular}{|l|} 
最大 \\
\end{tabular} & & & & \\
\hline \multirow{3}{*}{1956} & \multirow{3}{*}{ 横通他 ${ }^{25)}$} & \multirow{3}{*}{ 普通ポ } & \multirow{3}{*}{ 砂 f.m.2.73 } & \multirow{3}{*}{ 砂利 $25 \mathrm{~mm}$} & プレーン & 3 & 46.3 & 81.6 & 145 & 147 & 148 & 2.0 & 7.4 & 2.84 & 0.295 & - & \multirow{3}{*}{$\begin{array}{l}\text { 180分後の } \\
\text { 値 }\end{array}$} \\
\hline & & & & & 減水剂P & 3 & 40.6 & 72.2 & 127 & 129 & 130 & 2.0 & 6.0 & 9.89 & -0.281 & 28.4 & \\
\hline & & & & & 減水剂D & 3 & 41.2 & 72.2 & 127 & 130 & 133 & 3.1 & 6.4 & 9.41 & -0.226 & 24.1 & \\
\hline \multirow{3}{*}{1970} & \multirow{3}{*}{ 梶井他 ${ }^{14)}$} & \multirow{3}{*}{ 普通ポ } & \multirow{3}{*}{ 砂 f.m.2.82 } & & & 3 & 45.0 & 65.0 & 148 & 149 & 152 & 目標8 & & 10.9 & 0.033 & -3.0 & \\
\hline & & & & 砂利 $25 \mathrm{~mm}$ & $\mathrm{AE}$ 殽 & 3 & 45.0 & 65.0 & 159 & 160 & 163 & 目標1: & & 11.3 & -0.214 & 20.8 & \\
\hline & & & & & & 3 & 45.0 & 65.0 & 177 & 178 & 181 & 目標2 & & 14.7 & -0.417 & 20.8 & \\
\hline 1972 & & 解ポ & U砂 $25 \mathrm{~mm}$ & 矺石 2005 & $7+2+3$ & 2 & 55.0 & 65.0 & 188 & 190 & 191 & 14.3 & 16.5 & 12.5 & -0.426 & 34.0 & \\
\hline 1972 & 友滗他 & 小 & $.0 \mathrm{~mm}$ & 碎石2005 & J & 2 & 55.0 & 65.0 & 214 & 215 & 216 & 20.3 & 22.3 & 34.4 & -1.546 & 44.9 & \\
\hline 1978 & 中川 ${ }^{19)}$ & 普通ポ & 川砂 f.m.2.80 & 砂利 $20 \mathrm{~mm}$ & AE減水剂 & 3 & 50.0 & 70.0 & 174 & 175 & 176 & 18.0 & 19.0 & 8.50 & -0.210 & 24.7 & \\
\hline 1985 & 麻生他 ${ }^{26)}$ & 普通ポ & 海砂 f.m.2.47 & 砕石 $20 \mathrm{~mm}$ & プレーン & 3 & 45.0 & 65.0 & & 213 & & $\mid 18.0$ & 18.0 & 10.3 & -0.255 & 24.8 & \\
\hline 1985 & 岐阜生コン 27$)$ & 普通ポ & 川砂混合 & 砂利 $25 \mathrm{~mm}$ & $\mathrm{AE}$ 剤 & 3 & 45.0 & 65.0 & 158 & 160 & 163 & 目標7 & $\sim 10$ & 4.18 & -0.049 & 11.8 & $16 \sim 18^{\circ} \mathrm{C}$ \\
\hline & & & & & & 3 & 45.0 & 65.0 & & 233 & - & - & - & 5.00 & -0.095 & 19.0 & \\
\hline 1987 & 麻生他 ${ }^{28)}$ & 普通ポ & 海砂f.m.2.47 & 砕石 $20 \mathrm{~mm}$ & プレーン & 3 & 45.0 & 65.0 & - & 199 & - & - & - & 3.50 & -0.079 & 22.6 & \\
\hline & & & & & & 3 & 45.0 & 65.0 & - & 183 & - & - & - & 3.00 & -0.078 & 26.1 & \\
\hline 1993 & 青森生コン 29) & 普通ポ & 山砂＋砕砂 & 砕石 $20 \mathrm{~mm}$ & $\mathrm{AE}$ 減水剮 & 3 & 45.0 & 55.0 & 181 & 182 & 184 & & & 6.00 & -0.220 & 36.7 & \\
\hline 1997 & 田中他 ${ }^{30)}$ & 普通ポ & 研砂十細砂 & 砕石 $20 \mathrm{~mm}$ & AE減水剤 & 3 & 45.0 & 65.0 & - & 184 & - & 目標18 & & 12.7 & -0.245 & 19.3 & \\
\hline 2000 & 陶化 & 恶诵ポ & 海砂 f.m.2.88 & 砕石 $20 \mathrm{~mm}$ & AE減水剂 & 3 & 45.0 & 65.0 & - & 175 & - & 目標12 & & 9.50 & \begin{tabular}{|l|}
-0.263 \\
\end{tabular} & 27.6 & \\
\hline & 陶他 & 音通小 & 海砂 f.m.2.52 & & AL诲小们 & 3 & 45.0 & 65.0 & - & 173 & - & 目標8 & & 2.75 & -0.088 & 32.0 & \\
\hline & & & 海砂 & & & 2 & 50.0 & 60.0 & - & 180 & - & & & 16.4 & -0.554 & 33.8 & $17 \sim 18^{\circ} \mathrm{C}$ \\
\hline 2005 & 直自化 & 诵ポ & 海砂 $7+$ 砕砂 3 & 砕石 $20 \mathrm{~mm}$ & AF減水 & 2 & 50.0 & 60.0 & - & 178 & - & 西18 & & 15.7 & -0.542 & 34.5 & \\
\hline 2000 & 具鳥他 & 通小 & 海砂 $5+$ 砕砂 5 & 硗石 $20 \mathrm{~mm}$ & AE何我 & 2 & 50.0 & 60.0 & 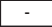 & 176 & - & 7日你18 & & 13.0 & -0.437 & 33.5 & \\
\hline & & & 砵砂 f.m.2.70 & & & 2 & 50.0 & 60.0 & - & 174 & - & & & 9.27 & -0.278 & 30.0 & \\
\hline 2008 & 因幡他 ${ }^{33)}$ & 普通ポ & 山砂+陸砂 & 砕石 $20 \mathrm{~mm}$ & $\mathrm{AE}$ 減水剮 & 2 & 55.0 & 65.0 & - & 170 & - & 18.5 & 19.0 & 6.00 & -0.100 & 16.7 & \\
\hline
\end{tabular}

\section{7. 既往の実験結果への適合性}

ここでは、以下の 3 つの場合について既往のブリーディング推定 式と本研究で提案する式との比較を行い、図 $15 \sim 17$ に示す。

\section{1 西らの式 ${ }^{12)}$ との比較}

西らは、ブリーディングは単位水量より単位細骨材量との相関が 強いとして、粗骨材の種類および細骨材の粒度ごとに式 ${ }^{12)}$ を示して いる。図 15 には、ブリーディング量の実測值と計算值の関係を、西 らの場合と本研究の場合を比較して示す。西らの場合には、プレー ンコンクリートと混和剤を使用した場合で式の係数を変えていない
ため、本研究の場合も同じ係数で計算值を算出している。これによ ると、西らの提案する式より、本研究による式のほうが適合性はよ くなっているといえる。

\section{2 佐治らの式 ${ }^{13)}$ との比較}

佐治らは、水セメント比 $(60 \% 、 70 \%)$, 細骨材の粒度（細砂、粗 砂）を組み合わせたコンクリートにより、粗骨材、細骨材の実積率 およびセメントや細骨材の保水性能を考慮し、コンクリートの沈降 量をブリーディング量と見なしてその推定式を作成した。図 16 に は、前記と同様の比較を示す。これによると、佐治らおよび本研究 

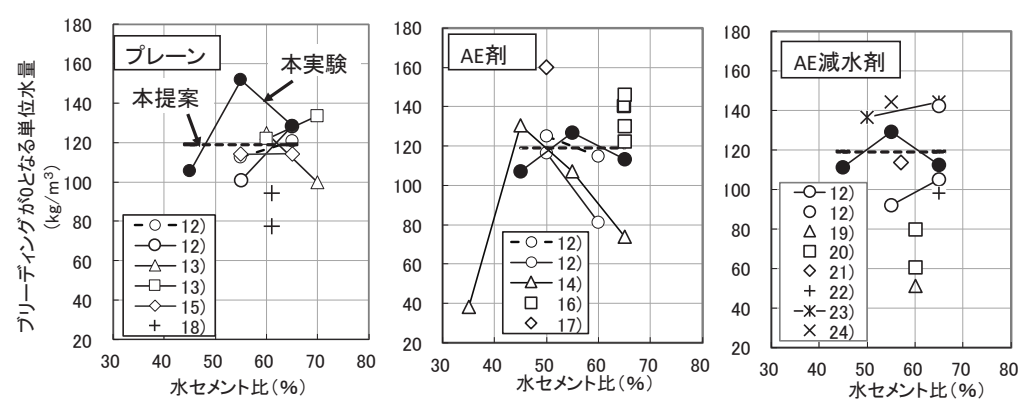

図 10 ブリーディングが○になる単位水量
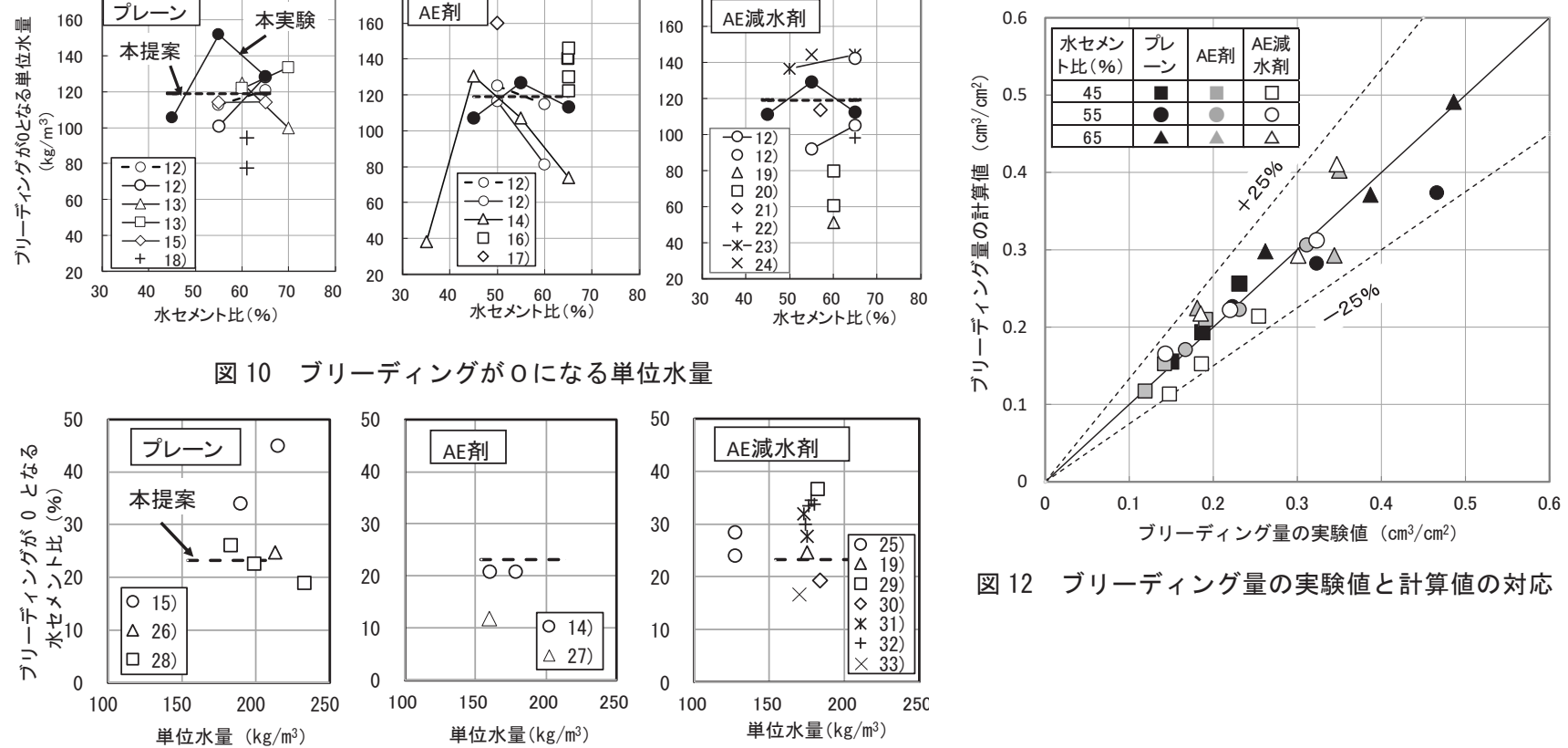

図 12 ブリーディング量の実験值と計算値の対応

図 11 ブリーディングが○になる水セメント比

のいずれもほぼ同等の対応を示しているといえる。

\section{3 梶井らの式 ${ }^{14)}$ との比較}

梶井らは、水セメント比 $35 \sim 65 \%$ 、スランプ 8～21cm、温度 10 $\sim 30^{\circ} \mathrm{C}$ 、骨材の種類 3 種類という膨大な実験を行っている。このう ち、水セメント比 $45 \sim 65 \%$ 、スランプ 8〜 $21 \mathrm{~cm}$, 温度 $20^{\circ} \mathrm{C}$ 、砂利・ 砂を用いた場合について比較を行った。ブリーディング率で示され た梶井らの式をブリーディング量で表示すると、次のようになる。

$$
\mathrm{B}=0.00904 \mathrm{~W}(\mathrm{w} / \mathrm{c}-30) / 100
$$$$
\cdot \cdot(2)
$$

また、本研究の式を適用した結果を次式に示す。

$$
\mathrm{B}=0.0350 \quad(\mathrm{~W}-119) \quad(\mathrm{w} / \mathrm{c}-23.2) / 100
$$

図 17 には、 7.1 と同様の比較を示している。梶井らの場合につい ては、式（2）からもわかるように、ブリーディング量が単位水量そ のものに比例するとしているため、実験值におけるブリーディング 量の増加に対して計算值の増加が小さくなっている。なお、梶井ら の場合は、全般に実験值より計算值のほうが小さくなっているが、 これは梶井らは水セメント比や温度条件が本実験より広範囲にわた るデータを対象に式を作成していることも一因と考えられる。

\section{8． 混和剂の効果に関する適用事例}

\section{1 コンクリート用化学混和剂協会のデータによる検討}

混和剂の効果を検討するため、コンクリート用化学混和剂協会よ り提供を受けたデータ（AE 剂 4 銘柄：基準コンクリートと試験コ ンクリート各 8 件、 $\mathrm{AE}$ 減水剂 6 銘柄: 同各 13 件、1998～2010 年) のうち、同一産地の骨材を使用した各 19 件に式(1)を適用して $\alpha$ を 算出した結果を図 18 に示す。これによると、プレーンコンクリー 卜の $\alpha$ と混和剤を用いたコンクリートの $\alpha$ は比較的よく対応してお り、 $\mathrm{AE}$ 剂を使用した場合は平均でプレーンコンクリートの 0.97 倍 となり、 $\mathrm{AE}$ 減水剂を使用した場合は平均で 1.04 倍となった。また、 基準コンクリートであるプレーンコンクリートの $\alpha$ の值も、骨材の ロットの相違によるところが大きいと考えられるが、0.005 から

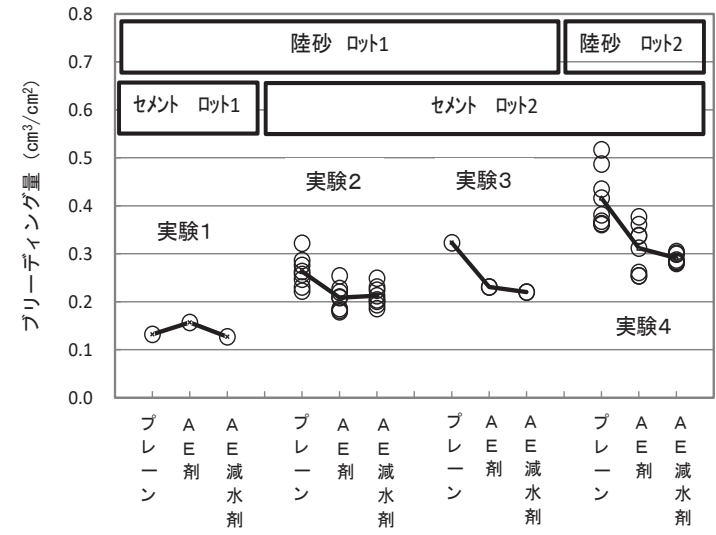

図 13 各実験におけるブリーディング量の比較

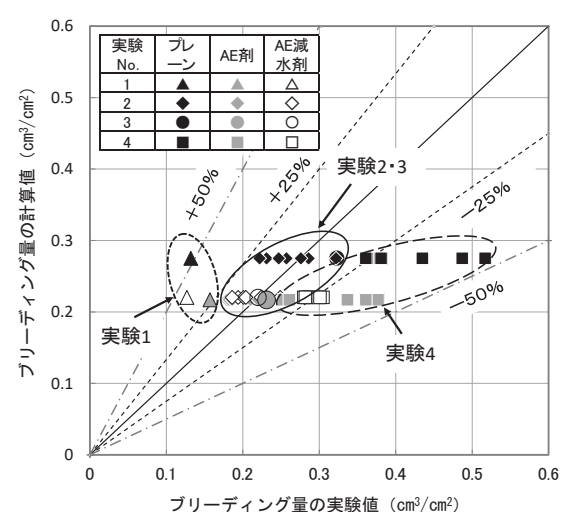

図 14 実験 3 の結果を適用した実験値と計算值の対応

0.014 までかなり大きく変化することが分かった。

図 19 は $\alpha$ の平均值を産地の異なる骨材にも適用して、実験值と 計算值の対応をみたものであるが、砂の異なる場合には対応の悪く なる場合が認められた。

\section{2 建材試験センターのデータによる検討}

文献 34)に使用されたデータを用いて、プレーンコンクリートで 

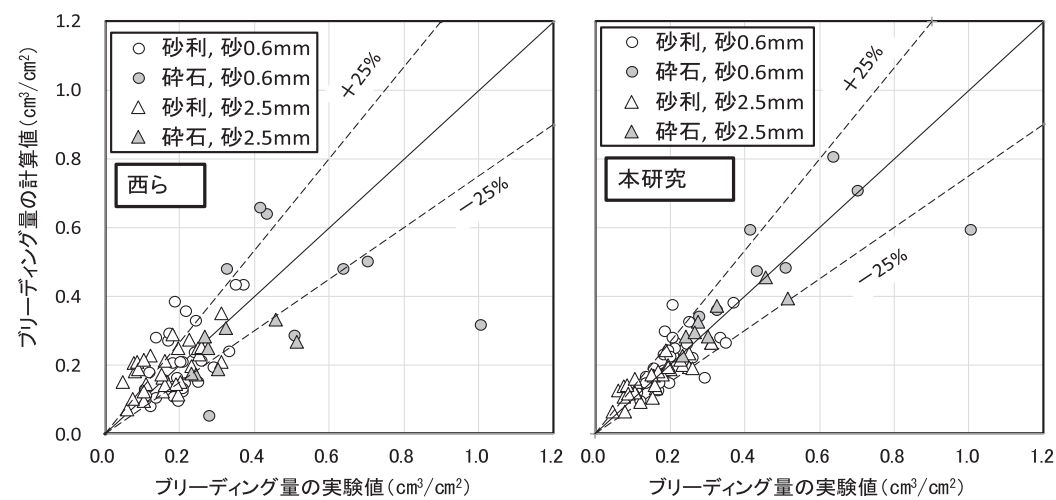

図 15 西らの式との比較
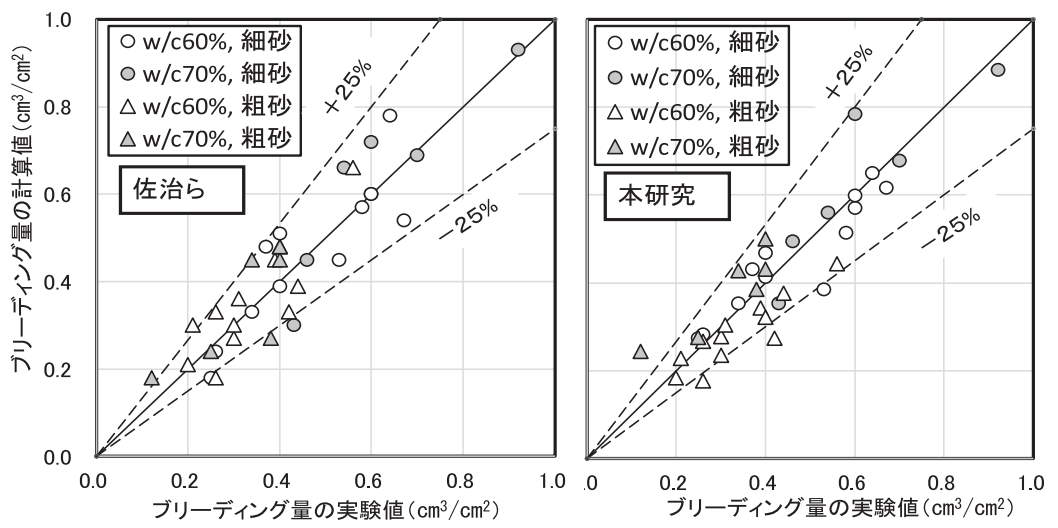

図 16 佐治らの式との比較
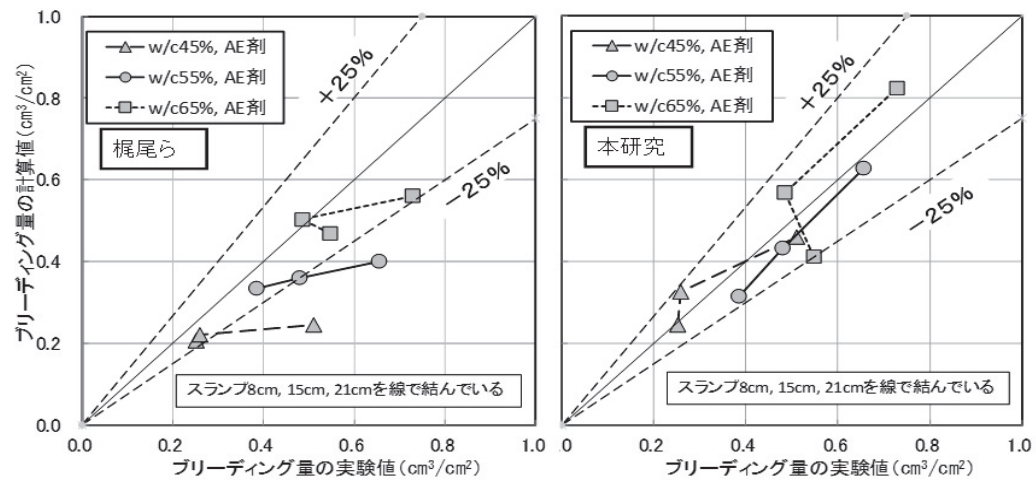

図 17 梶井らの式との比較

ある基準コンクリートおよび混和剤を用いた試験コンクリートそれ ぞれについて $\alpha$ の值を求めた。この一連の試験では同じ産地の骨材 を用い、セメントは 3 銘柄等量混合であるが、プレーンコンクリー トの $\alpha$ は、データ数 141 で、最大 0.0241 、最小 0.0050 、平均 0.0115 、 標準偏差（ $\sigma$ n $) 0.027$ となり、かなり幅のある結果となった。

図 20 は、プレーンコンクリートの $\alpha$ と混和剤を用いたコンクリ 一トの $\alpha$ を比較したものであるが、混和剤の種類により両者の関係 がやや異なること、また、 $\mathrm{AE}$ 剤や減水剤を使用した場合に比べて、 $\mathrm{AE}$ 減水剂や高性能 $\mathrm{AE}$ 減水剂を使用した場合のほうが、 $\alpha$ の範囲 が大きくなっている傾向が認められ、後者のほうがブリーディング に及ぼす銘柄(成分)の影響が大きいことを示しているともいえる。

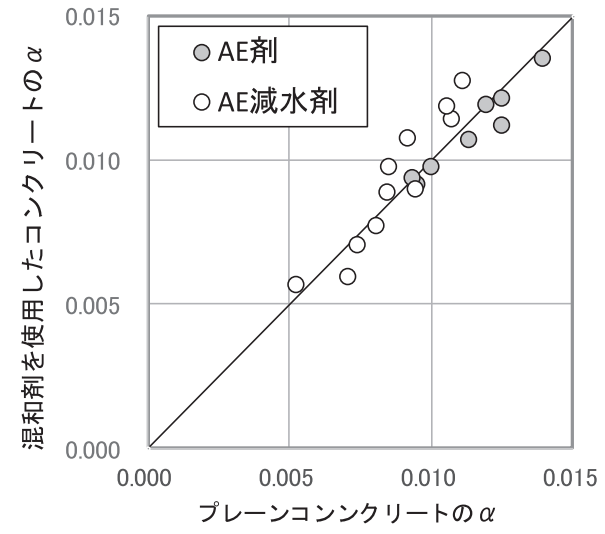

図 18 プレーンコンクリートの $\alpha$ と混和剂を使 用したコンクリートの $\alpha$ の比較

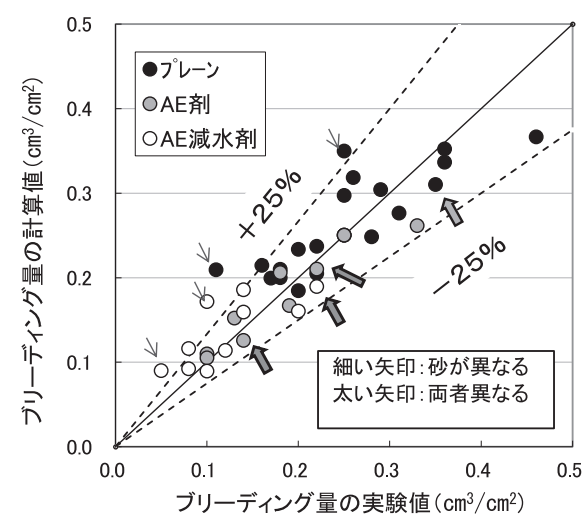

図 19 ブリーディング量の実験值と計算值の対 応（コンクリート用化学混和剂協会のデータ）

表 8 は、プレーンコンクリートの $\alpha$ に対する混 和剤を用いたコンクリートの $\alpha$ の比を示したも ので、この值は、水セメント比と単位水量の影響 を除いた場合のブリーディングへの影響の度合 いを示している。たとえば、 $\mathrm{AE}$ 剂であれば、そ れを用いることによる水セメント比と単位水量 の減少分に相当するブリーディングの抑制効果 が期待できることになり、減水剤であれば、標準 形の場合にはそれ以上の効果が期待できるが、遅 延形ではそれが期待できないこととなる。また、同じく建材試験セ ンターで実施された文献 35)の結果と比較すると、一部に逆のもの もあるが、全般にブリーディングに関して混和剤の性能が改善され ていることを読み取ることができる。

図 21 は、表 9 の $\alpha_{2} / \alpha_{1}$ を各基準コンクリートの $\alpha$ に乗じてブリ ーディング量の計算值を算出し、実験值との対応をみたものである。 これによると、図 20 からも推測されるように、 $\mathrm{AE}$ 剂や減水剂を使 用した場合に比べて、 $\mathrm{AE}$ 減水剂や高性能 $\mathrm{AE}$ 減水剂を使用した場 合のほうが、ブリーディング量の少ない領域ではあるが、やや対応 が悪くなっていることがわかる。 

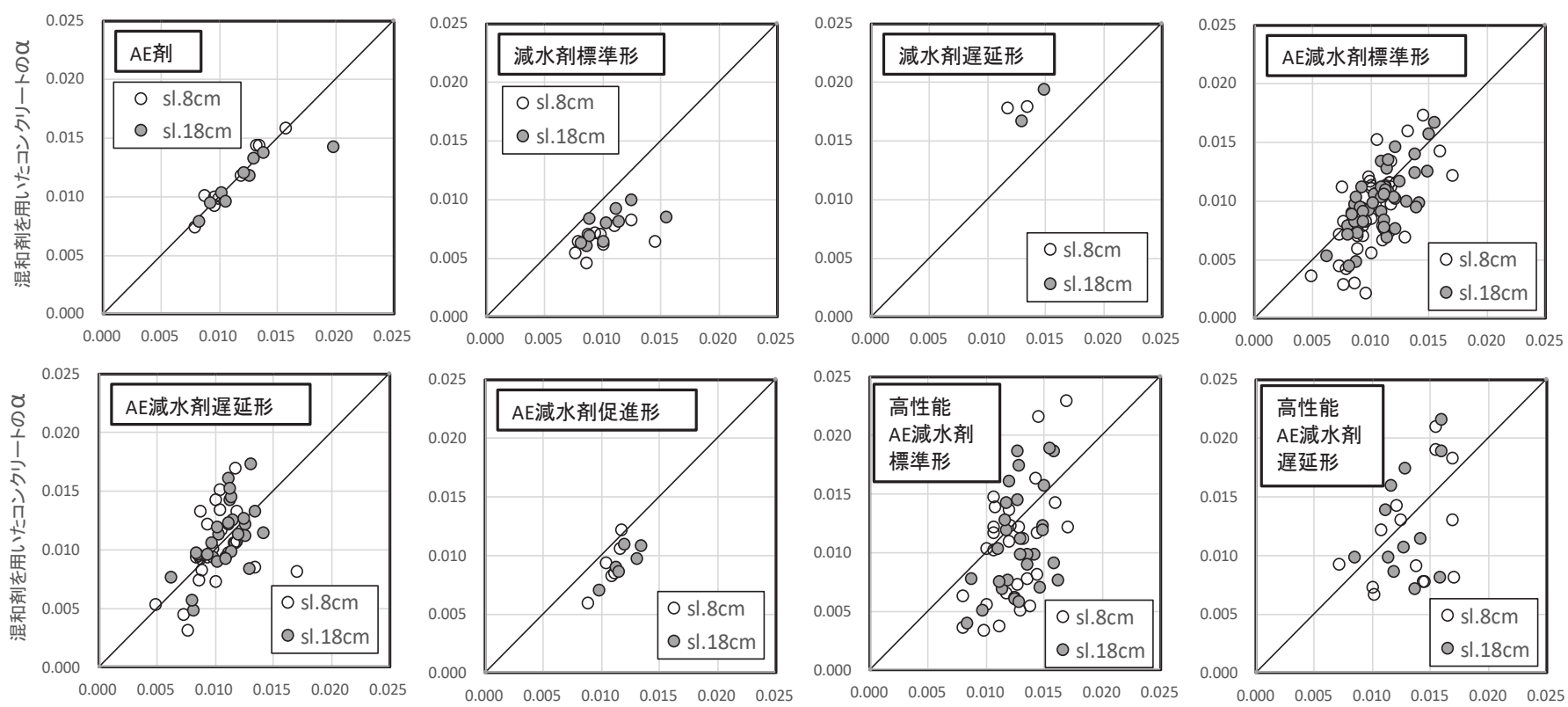

プレーンコンクリートの $\alpha$

プレーンコンクリートの $\alpha$

プレーンコンクリートの $\alpha$

図 20 プレーンコンクリートの $\alpha$ と混和剂を使用したコンクリートの $\alpha$ の比較
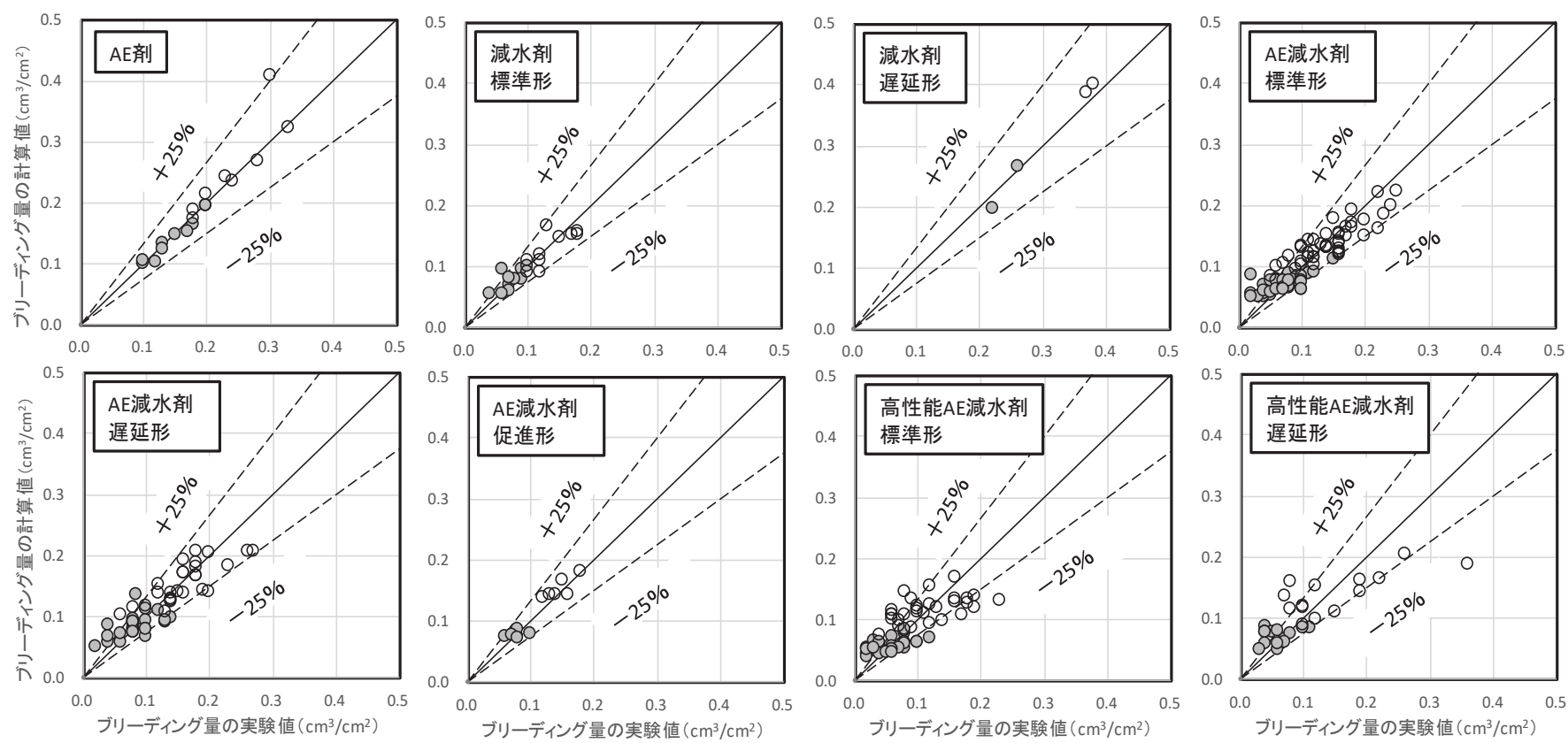

図 21 ブリーディング量の実験値と計算値の対応

表 8 基準コンクリートと試験コンクリートの実験定数 $\alpha$

\begin{tabular}{|c|c|c|c|c|c|c|c|c|c|c|c|c|c|c|c|}
\hline \multirow{3}{*}{\multicolumn{2}{|c|}{ 混和剤の種類 }} & \multicolumn{5}{|c|}{ スランプ $8 \mathrm{~cm}$} & \multicolumn{5}{|c|}{ スランプ $18 \mathrm{~cm}$} & \multicolumn{3}{|c|}{$\alpha_{2} / \alpha_{1}$ の平均 } & \multirow{3}{*}{\begin{tabular}{|l|} 
前回と \\
今回 \\
の比 \\
\end{tabular}} \\
\hline & & \multicolumn{2}{|c|}{ 基準コンクリー卜 } & \multicolumn{2}{|c|}{\begin{tabular}{|l|l|} 
試験コンクリリト \\
\end{tabular}} & \multirow{2}{*}{$\begin{array}{l}\alpha_{2} \\
/ \alpha_{1}\end{array}$} & \multicolumn{2}{|c|}{ 基準コンクリー卜 } & \multicolumn{2}{|c|}{ 試験コンクリート } & \multirow{2}{*}{$\begin{array}{c}\alpha_{2} \\
/ \alpha_{1}\end{array}$} & \multirow{2}{*}{$\begin{array}{c}\text { 今回 }^{34)} \\
\text { 值 }\end{array}$} & \multicolumn{2}{|c|}{ 前回 ${ }^{35)}$} & \\
\hline & & $\mathrm{n}$ & $\alpha$ & $\mathrm{n}$ & & & $\mathrm{n}$ & $\alpha$ & $\mathrm{n}$ & $\alpha$ & & & $\mathrm{n}$ & 值 & \\
\hline \multicolumn{2}{|c|}{$\mathrm{AE}$ 剂 } & 9 & 0.0112 & 9 & 3 & 1.02 & 8 & & 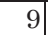 & & 0.92 & 0.97 & 12 & 0. & 1.00 \\
\hline \multirow{2}{*}{ 減水剤 } & 標準 & 10 & 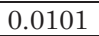 & 10 & 5 & 0.65 & 10 & & 10 & & 0.7 & 0 & & & 0.79 \\
\hline & & 2 & & 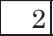 & & 1. & & & & & 1. & & & & .17 \\
\hline \multirow{3}{*}{$\mathrm{AE}$ 減水剤 } & & 4 & & 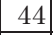 & & $0.8^{\prime}$ & & & 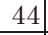 & & 0.5 & 0.89 & 0 & & .85 \\
\hline & 遅延形 & 27 & & 27 & & 0.98 & 27 & & 27 & & 1.0 & & 6 & & .88 \\
\hline & & 6 & & & & 0. & & & & & 0. & & 17 & & .90 \\
\hline \multirow{2}{*}{$\begin{array}{c}\text { 高性能 } \\
\mathrm{AE} \text { 減水剂 }\end{array}$} & & 29 & & 29 & & 0.83 & 29 & & 29 & & 0. & & 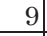 & 0. & 1.07 \\
\hline & 遅延形 & 14 & 0.0134 & 14 & 0.0118 & 0.88 & 14 & 0.0146 & 14 & 0.0164 & 1.12 & 1.00 & 4 & 1.10 & 0.91 \\
\hline
\end{tabular}

注） $\alpha_{1}$ :プレーンコンクリートである基準コンクリートの $\alpha 、 \alpha_{2}$ : 混和剤を使用した試験コンクリートの $\alpha$ 


\section{9. まとめ}

本研究の結果は以下のようにまとめられる。

（1）ブリーディング量は混和剤の種類が同一の場合、単位水量およ び水セメント比の減少とともにほぼ直線的に減少するとみなして差 し支えないことが確認された。

（2）水セメント比 1 水準であるが、ブリーディング試験におけるバ ッチ間やバッチ内のばらつきのデータを得ることができ、プレーン コンクリートではバッチ内のばらつきが大きいことが把握された。

（3）単位水量および水セメント比を考慮したブリーディング予測式 を作成し、既往の式と比較しても遜色のない結果が得られた。

（4）ブリーディング予測式における実験定数 $\alpha$ は、使用材料の銘柄 や産地が同じでも、ロットなどにより 3〜4倍程度の幅をもつこと、 寸なわちブリーディング量が同じ $3 \sim 4$ 倍程度の幅をもつことが把握 された。今後、 $\alpha$ の值に及ぼすセメントや細骨材の品質の影響につ いて検討する必要がある。

（5）混和剤を使用した場合について、プレーンコンクリートの $\alpha$ に 乗ずる係数を混和剤の種類ごとに示したが、 $\mathrm{AE}$ 㓮や減水剤に比べ、 $\mathrm{AE}$ 減水剂や高性能 $\mathrm{AE}$ 減水剂では、ブリーディング量の実験值と 計算值の対応がやや劣る結果となった。

\section{謝辞}

実験に際し、当時工学院大学卒論生であった石橋涼君をはじめ、 卒論生各位の協力を得ました。また、コンクリート用化学混和剂協 会および宇部三菱セメントからは、データの提供を受けました。記 して謝意を表します。

\section{参考文献}

1）日本建築学会：建築工事標準仕様書 JASS 5 鉄筋コンクリート工事, p. 505, 2015. 7

2) 日本建築学会材料施工委員会 : 鉄筋コンクリート工事の現状と今後の課 題, 建築雑誌, Vol. 87, No. 1056, pp. 931-935, 1972. 9

3）仲摩諭，阿部道彦：コンクリートのブリーディングに及ぼす各種要因の 影響に関する実験, 日本建築学会大会学術講演梗概集, 材料施工, pp. 263-264，2013. 8

4）仲摩諭，石橋涼，阿部道彦：コンクリートのブリーディングに及ぼす各 種要因の影響, 日本建築学会関東支部研究報告集, No. 84 (I), pp. 121-124, 2014. 3

5）阿部道彦, 仲摩諭, 石橋涼 : コンクリートのブリーディング予測式の作 成に関する実験, 日本建築学会大会学術講演梗概集, 材料施工, pp. 529-530, 2014. 9

6）日本建築学会：コンクリートの調合設計指針・同解説，p. 10，1999. 2

7）阿部道彦，斉藤正城：モルタルによるブリーディング試験方法に関する 検討，日本建築学会大会学術講演梗概集，A-1，pp. 277-278，2004.8

8）永島明夫, 平田隆祥, 竹田宣典 : ブリーディング試験結果に及ぼす測定 方法の影響，土木学会第 50 回年次学術講演会講演梗概集 V, pp. 1010-1011，1995.9

9）十代田知三: コンクリートのブリージング試験について、日本建築学会 大会学術講演梗概集，構造系，pp. 69-70，1984. 10

10）高畑友彦，高橋敏樹，青木一久：測定条件の違いがブリーディング試験 の結果に及ぼす影響, 土木学会第 57 回年次学術講演会講演梗概集 V, pp. 1449-1450, 2002. 9

11）麻生実, 島添洋治, 白川敏夫 : モルタル・コンクリートのブリージング に関する研究，日本建築学会九州支部研究報告，第 29 号，pp. 21-24, 1986. 3

12）西忠雄, 長島弘, 山川哲郎：コンクリートのブリージングについて、セ メント技術年報，第 10 巻，pp. 313-319， 1956

13) 佐治泰次, 松藤泰典: 軟練りコンクリートの沈降現象と調合について（第 1 報），日本建築学会論文報告集，第 138 号，pp．1-6，1967. 8
14）梶井基彦，平山勇，森脇明行，河村一正：砂利および軽量コンクリート のブリージング性状について，セメント技術年報，第 24 巻，pp. 369374,1970

15）友澤史紀，五十畑新一：ブリーディング試験方法に関する研究，昭和 46 年度建築研究所年報, pp. 353-356, 1972. 2

16）秋山憲男，今井茂，井出昌男，古越浩一，中井裕：コンクリート用細骨 材としての砕砂 $(2.5 \sim 0)$ の利用，骨材資源，通巻 No. 26，pp. 8-31, 1975

17）友澤史紀，川瀬清孝，赤石博，田中斉：コンクリート用骨材としての砕 砂に関する実験的研究, 日本建築学会大会学術講演梗概集, 構造系, pp. $45-46,1976.10$

18) 十代田知三: コンクリートの内部構造におよぼすブリージングの影響, 学 位論文, pp. 7-12，1978. 3

19）中川脩：水砕スラグ細骨材コンクリートの調合と性質（その 2 ），コン クリート用水砕スラグ細骨材の使用規準の作成に関する研究報告書, 社 団法人日本鉄鋼連盟コンクリート用水砕スラグ細骨材使用規準作成研究 会, II -D-1-30， 1978. 3

20）依田彰彦，横室隆，大平光洋：水砕スラグ砕砂に川砂・海砂を混用した モルタル及びコンクリートについて，第 1 回コンクリート工学年次論文 集，pp. 177-179， 1979

21）池田正志, 岸谷孝一, 嵩英雄, 飯塚正則 : 流動化コンクリートの工学的 性質に関する実験的研究，第 3 回コンクリート工学年次論文集，pp. 4548, 1981

22）大分生コンクリート工業組合スラッジ対策研究会・産業廃棄物利用研究 会：乾燥スラッジを混入したコンクリートの特性, 第 7 回生コン技術大 会研究発表論文集，pp. 69-74，1993

23）薬師寺照夫，松本皇月，田口茂久，佐藤嘉昭：微粉砕乾燥スラッジ混入 コンクリートの特性，第 9 回生コン技術大会研究発表論文集，pp. 9196, 1997

24）木村博明，片山一司，藤村大輔，河野晋一郎：各種要因が及ぼすブリ一デ イングの傾向について，第 14 回生コン技術大会研究発表論文集，pp. 16, 2007

25）横通英雄，一木保夫，松井司：セメント拡散剂および $\mathrm{AE}$ 剂がコンクリー トのスランプ、強度およびブリージングにおよぼす影響の比較，セメン 卜技術年報，第 10 巻，pp. 194-199， 1956

26）麻生実，島添洋治，白川敏夫：モルタル・コンクリートのブリージング に関する一考察, 日本建築学会大会学術講演梗概集， A， pp. 517-518， 1985. 10

27）岐阜県生コンクリート工業組合他：A・B・C 種高炉セメントを用いたコン クリートについて，第 4 回生コン技術大会論文集，pp. 149-154，1985

28）麻生実，島添洋治，白川敏夫：コンクリートのブリージングに関する一 考察，日本建築学会大会学術講演梗概集， A, pp. 95-96, 1987. 10

29）青森生コン協同組合技術部会，青森生コン工業組合：高耐久性コンクリ 一トの基礎物性に関する実験，第 7 回生コン技術大会研究発表論文集, pp. $167-170,1993$

30）田中敏，霜出秋徳，河合栄一，茶園光秋，高柳藤夫，関野一男：都市ゴ ミ焼却灰を原料としたセメントを用いたコンクリートの諸性状及び現場 への適用，第 9 回生コン技術大会研究発表論文集，pp. 47-52, 1997

31）陶佳宏，松下博通，鶴田浩章，上田哲史：打継ぎによるコンクリートの 強度低下に関寸る研究，コンクリート工学年次論文集，Vol. 22，No. 1, pp. 265-270, 2000

32）真鳥信秋，持永真二，田中信也，白倉純一，小松武史：海砂の代替とし て石灰石砕砂を使用したコンクリートの性状について, 第 13 回生コン 技術大会研究発表論文集，pp.17-20，2005

33）因幡芳樹，守屋健一，金子樹，嵩英雄：コンクリートの打重ね部の付着 強度に及ぼす打重ね時間間隔とセメント種類の影響, 日本建築学会構造 系論文集，Vol.73，No.631，pp. 1443-1448，2008．9

34）志村明春，鈴木澄江：過去 10 年間に実施した「コンクリート用化学混和 剂」の品質試験結果について, 建材試験情報, Vol. 39, No. 10, pp. $17-24,2003$

35）飛坂基夫, 岸賢蔵, 柳啓 : コンクリート用化学混和剂の品質一高性能 $\mathrm{AE}$ 減水剂を含む一，第 5 回生コン技術大会研究発表論文集，pp. 125-130, 1989 


\title{
EXPERIMENTAL STUDY ON ESTABLISHMENT OF PREDICTION EQUATION OF BLEEDING OF CONCRETE
}

\author{
Michihiko ABE ${ }^{*}$, Satoru NAKAMA** and Sumie SUZUKI ${ }^{* * *}$ \\ * Prof., School of Architecture, Kogakuin Univ., Dr. Eng. \\ ** Higashikyushu Architectural \& Engineering, Inc., M. Eng. \\ *** Japan Testing Center for Construction Materials, Dr. Eng.
}

Because of environmental consideration and variety of required performance for concrete, the kinds of constituent materials used for concrete have been increased. For this reason the bleeding of concrete has shown a high value in some cases. It is said that higher bleeding has some harmful effects on the properties of concrete and reinforcement but the method for control of bleeding have not been proposed.

This paper presents the results of experimental study and the literature survey on the simple prediction model of bleeding of concrete.

The experiment was composed of four series and the bleeding test of concrete was conducted in accordance with JIS A 1123 except for the interval of taking the rising water. In series 1, unit water content and the kind of chemical admixtures were varied under the constant water cement ratio. In series 2 , the variation of bleeding in the different 7 batches was checked. In series 3, unit water content, water cement ratio and the kind of chemical admixtures were varied. In series 4 , the variation of 7 bleeding test samples in the same batch was checked. Based on the series 2 a simple prediction equation of bleeding was established.

And a literature survey on bleeding of concrete in Japan was conducted and the data of experiments in which unit water content or water cement ratio are varied under the other condition is constant were set in order.

Moreover the comparison of the existing three prediction equations and the equation model of bleeding of concrete proposed in this paper was conducted.

At the last stage the effect of bleeding in the cases in which this proposed equation was adapted to those using with other chemical admixtures were considered based on the data provided by some organizations, because the concretes using with air-entraining agent and air-entraining and water-reducing agent were treated in this experiment.

The conclusions of this study are summarized as follows.

(1) It was confirmed that bleeding amount reduces linearly with the reduction of unit water content or water cement ratio.

(2) The data of variation in the different batches and that in the same batch were obtained, and in the latter case the variation of plain concrete was larger than that of concrete with air-entraining agent or air-entraining and water- reducing agent.

(3) The prediction equation of bleeding considering unit water content and water cement ratio was established, and it compares favorably with existing equations.

(4) The empirical constant coefficient in the prediction equation of bleeding had wide range of 3 or 4 times due to the lots of used materials even if the brand or district was the same. In other words, it was found that bleeding mass had the same range. Accordingly, it is necessary to study the influence of the quality of cement and fine aggregate on the empirical constant coefficient in the future.

(5) In the case where chemical admixtures were used, the coefficients which multiplies the empirical constant coefficient of plain concrete were shown in each kind of chemical admixture. The compatibility of experimental values and calculated values in the case of air-entraining and water-reducing agent or air-entraining and high range water-reducing agent was not so good compared to air-entraining agent or water-reducing agent. 